
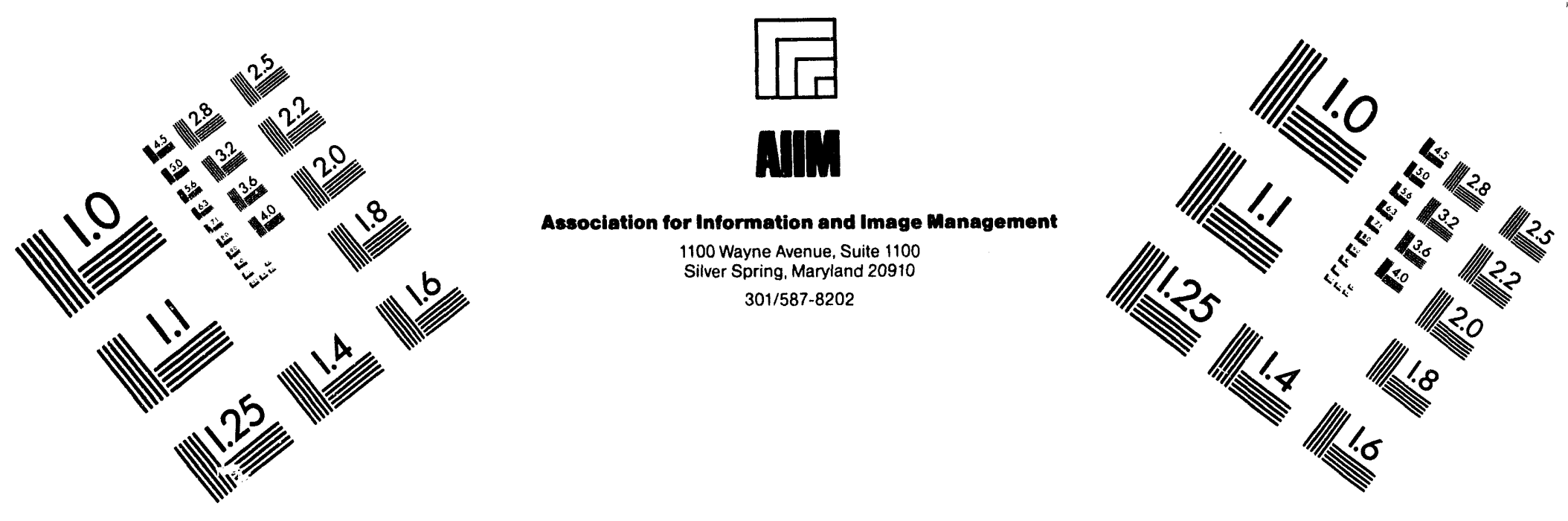

Centimeter

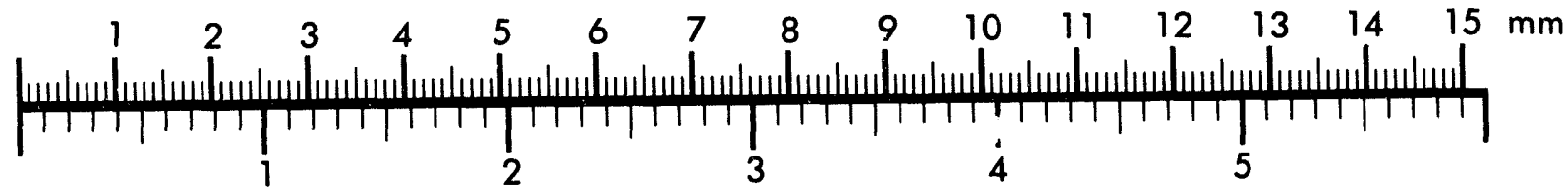
Inches

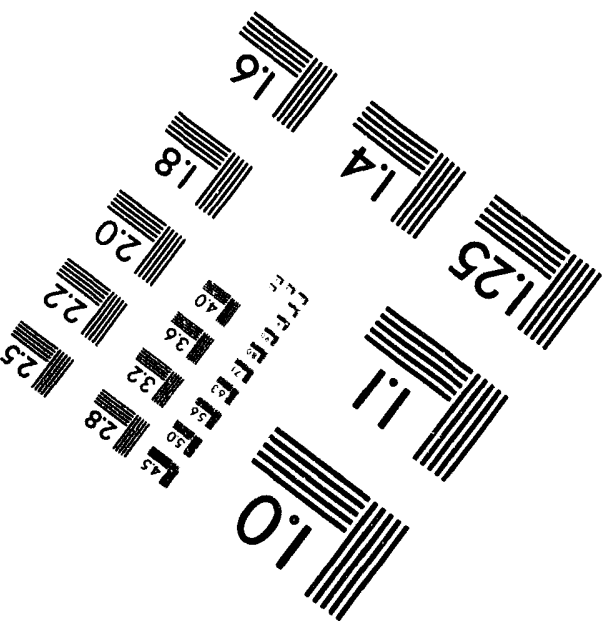

MANUFACTURED TO AIIM STANDARDS

BY APPLIED IMAGE, INC.

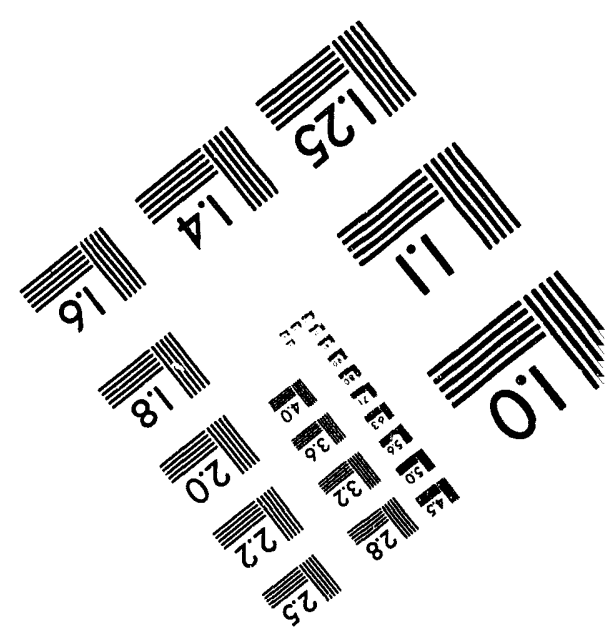



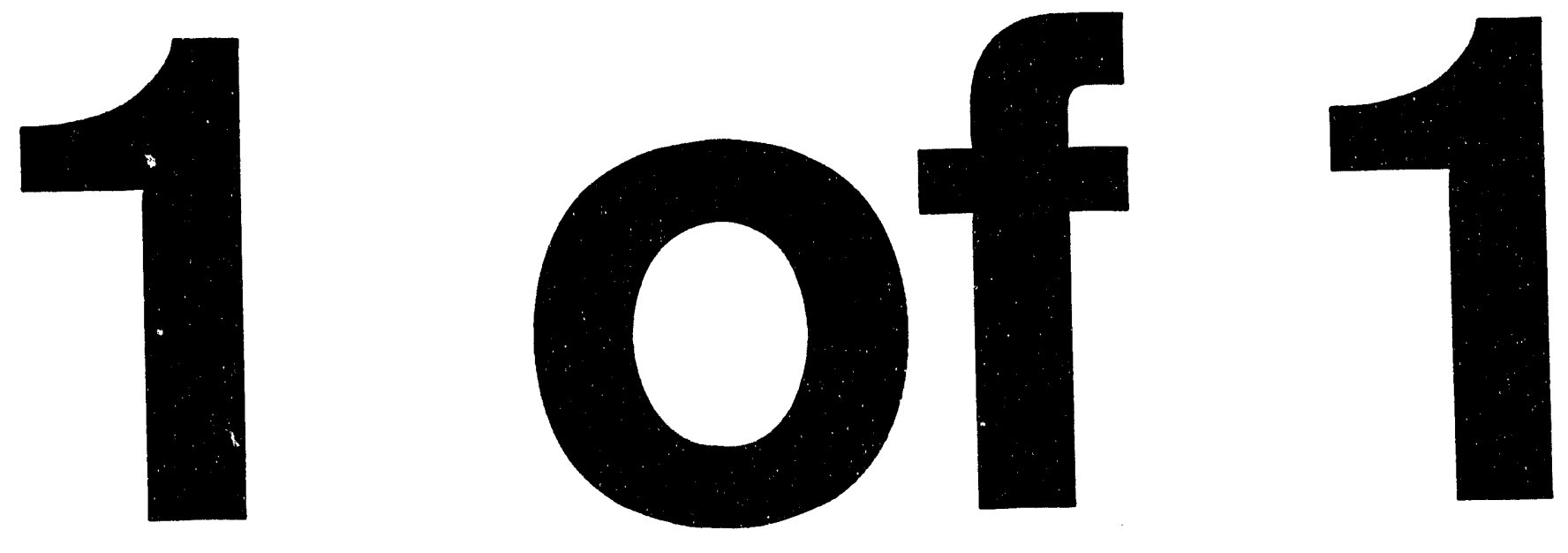
SAND92-0847

Distribution

Unlimited Release

Category UC-814

Printed July 1994

\title{
The Effect of Frequency on Young's Modulus and Seismic Wave Attenuation
}

\author{
R. H. Price \\ YMP Performance Assessment Applications Department \\ Sandia National Laboratories \\ Albuquerque, NM 87185 \\ R. J. Martin, III and R. W. Haupt \\ New England Research, Inc. \\ White River Junction, VT 05001
}

\begin{abstract}
Laboratory experiments were performed to measure the effect of frequency, water-saturation, and strain amplitude on Young's modulus and seismic wave attenuation on rock cores recovered on or near the site of a potential nuclear waste repository at Yucca Mountain, Nevada. The purpose of this investigation is to perform the measurements using four techniques: cyclic loading, waveform inversion, resonant bar, and ultrasonic velocity. The measurements ranged in frequency between $10^{-2}$ and $10^{6} \mathrm{~Hz}$.

For the dry specimens Young's modulus and attenuation were independent of frequency; that is, all four techniques yielded nearly the same values for modulus and attenuation. For saturated specimens, a frequency dependence for both Young's modulus and attenuation was observed. In general, saturation reduced Young's modulus and increased seismic wave attenuation. The effect of strain amplitude on Young's modulus and attenuation was measured using the cyclic loading technique at a frequency of $10^{-1} \mathrm{~Hz}$. The effect of strain amplitude in all cases was small. For some rocks, such as the potential repository horizon of the Topopah Spring Member tuff (TSw2), the effect of strain amplitude on both attenuation and modulus was minimal.
\end{abstract}

iii 
This report was prepared under the Yucca Mountain Project WBS number 1.2.3.2.7.1.3. The data in this report was developed subject to QA controls in QAGR S1232713; the data is not qualified and is not to be used for licensing. 


\section{CONTENTS}

Section

Page

1.0 INTRODUCTION $\ldots \ldots \ldots \ldots \ldots \ldots \ldots \ldots \ldots \ldots$

2.0 EXPERIMENTAL PROCEDURE $\ldots \ldots \ldots \ldots \ldots \ldots \ldots$

2.1 Cyclic Loading Experiments $\ldots \ldots \ldots \ldots \ldots$

2.2 Waveform Inversion $\ldots \ldots \ldots \ldots \ldots \ldots$

2.3 Resonant Bar Experiments $\ldots \ldots \ldots \ldots \ldots \ldots$

2.4 Ultrasonic Experiments $\ldots \ldots \ldots \ldots \ldots$

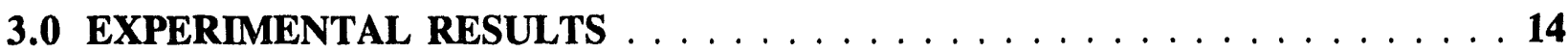

3.1 Topopah Spring Member Tuff/Busted Butte Outcrop . . . . . . . . . . . . 18

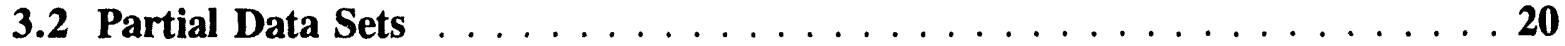

3.2 .1 Cyclic Load $\ldots \ldots \ldots \ldots \ldots$

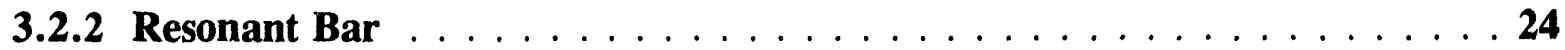

3.3 Ultrasonic Measurements . . . . . . . . . . . . . . . . . . . . . . 24

4.0 DISCUSSION $\ldots \ldots \ldots \ldots \ldots \ldots$

4.1 Young's Modulus: The Effects of Frequency and Water Saturation . . . . 44

4.2 Attenuation: The Effects of Frequency and Water Saturation . . . . . . . 45

4.3 Effect of Strain Amplitude on Modulus and Attenuation . . . . . . . . . . 46

5.0 CONCLUSIONS $\ldots \ldots \ldots \ldots \ldots \ldots$

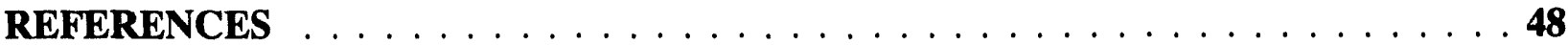

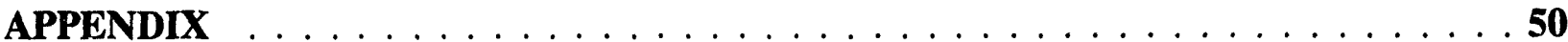


List of Figures

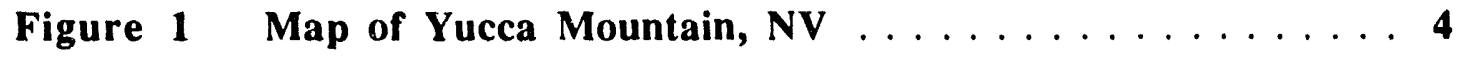

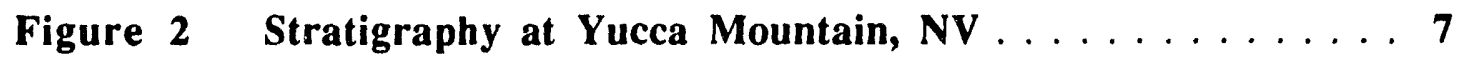

Figure 3 Schamatic of the Resonant Bar Apparatus ....... 10

Figure 4 Schematic of the Ultrasonic Velocity Apparatus . . . . . 12

Figure 5 Young's Modulus versus Frequency for TSw2 . . . . 15

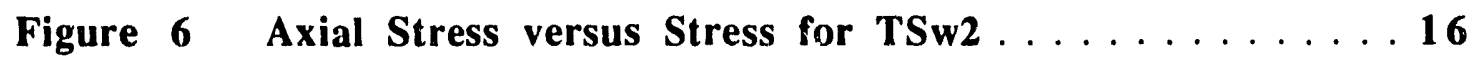

Figure 7 Compressional and Shear Waveforms for TSw2 . . . 17

Figure 8 Stress versus Strain for TSw2 in Uniaxial Compression . 19

Figure 9a Compressional and Shear Waveforms for TSw2 . . . 22

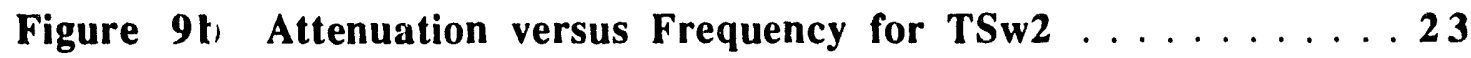

Figure 10 Data for Resonant bar Experiment on TSw2 . . . . . . 26

Figure 11 a Velocity versus Pressure for $\mathrm{TCw} \ldots \ldots \ldots \ldots \ldots$

Figure $11 \mathrm{~b}$ Attenuation Near $10^{6} \mathrm{~Hz}$ versus Pressure for $\mathrm{TCw} \ldots \ldots 41$

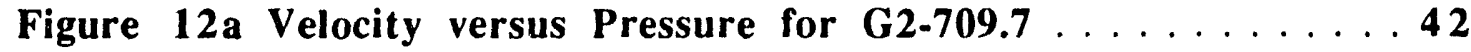

Figure 12b Attenuation Near $10^{6} \mathrm{~Hz}$ versus Pressure for G2-709.7 43

List of Tables

Table 1 Specimens for Modulus and $Q^{-1}$ Tests . . . . . . . 5

Table 2 Experimental Techniques and Specimen Size .......6

Table 3 Young's Modulus and $Q^{-1}$ for Tuff at $0.1 \mathrm{~Hz} \ldots \ldots 21$

Table 4 Resonant Bar and Waveform Inversion Data on Tuff . . . 25

Table 5a Compressional Wave, Shear Wave, and Attenuation Data

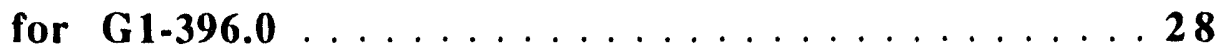

Table 5b Compressional Wave, Shear Wave, and Attenuation Data for $\mathbf{G 1 - 4 0 9 . 9 - A 1 \ldots \ldots \ldots \ldots \ldots \ldots}$

Table 5c Compressional Wave, Shear Wave, and Attenuation Data

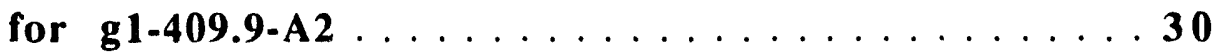

Table 5d Compressional Wave, Shear Wave, and Attenuation Data for $\mathbf{G 1 - 7 2 1 . 4 \ldots \ldots \ldots \ldots \ldots \ldots} 31$ 
Table 5e Compressional Wave, Shear Wave, and Attenuation Data

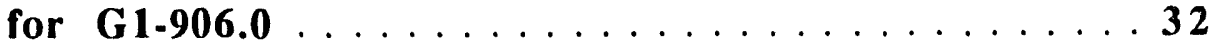

Table $5 \mathrm{f}$ Compressional Wave, Shear Wave, and Attenuation Data

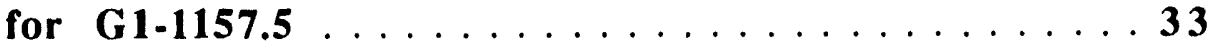

Table $5 \mathrm{~g}$ Compressional Wave, Shear Wave, and Attenuation Data for $\mathbf{G 1 - 1 4 0 6 . 3 \ldots \ldots \ldots \ldots \ldots \ldots \ldots}$

Table $5 \mathrm{~h}$ Compressional Wave, Shear Wave, and Attenuation Data for $\mathbf{G 2 - 7 0 9 . 7 \ldots \ldots \ldots \ldots \ldots \ldots \ldots \ldots}$

Table 5i Compressional Wave, Shear Wave, and Attenuation Data

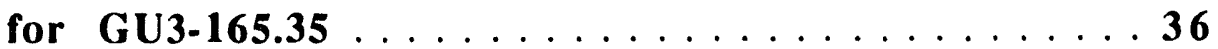

Table 5j Compressional Wave, Shear Wave, and Attenuation Data for $\mathbf{G U 3 - 2 1 1 . 3 \ldots \ldots \ldots \ldots \ldots \ldots}$

Table 5k Compressional Wave, Shear Wave, and Attenuation Data for $\mathbf{G 4 - 1 3 5 . 0 \ldots \ldots \ldots \ldots \ldots \ldots \ldots}$

Table 5I Compressional Wave, Shear Wave, and Attenuation Data for $\mathbf{G 4 - 1 6 1 7 . 7 5} \ldots \ldots \ldots \ldots 39$ 


\subsection{INTRODUCTION}

In light of the requirements for reliable input parameters into the rheological models for the potential nuclear waste repository at Yucca Mountain, a suite of measurements was carried out to study the effects of frequency, water saturation, and excitation strain amplitude on the elastic moduli and seismic wave attenuation on tuff. In most previous studies, only one measurement technique over a limited frequency band was employed. Therefore, to understand the complete frequency dependence for a specific rock, data on that rock from diverse sources were pieced together. The approach here was to use multiple techniques on the same rock core to determine Young's modulus, E, and extensional wave attenuation, $\mathrm{Q}_{\mathrm{E}}{ }^{-1}$, as a function of frequency, water saturation, and strain amplitude.

Seismic attenuation contributes significantly to the amplitudes and spectra of ground motion measured at the surface. Attenuation is greatest in soils (unconsolidated sediments); less, but significant, in consolidated sediments. Even at hard, crystalline rock sites, attenuation takes place mostly in the upper few kilometers of the crust (Toksöz et al., 1990). This is due primarily to physical mechanisms responsible for attenuation.

The three most important mechanisms for seismic attenuation are: (1) relative motions and the resulting friction across grain boundaries, microfractures, and between zones with different mechanical properties; (2) motions of fluids, such as water, induced by seismic waves; and (3) scattering of waves by the heterogeneity (i.e., mechanical properties contrasts) in rocks. Friction is the single most important mechanism for seismic attenuation at shallow depths. Because of low confining pressure and large surface areas that are not bound strongly, seismic waves easily cause motions and loss of energy due to friction (Walsh, 1969; Mavko and Nur, 1979; and Toksöz and Johnston, 1981). At greater depths the grains are bound more strongly due to overburden pressure, compaction, and lithification. Relative motions between grains induced by the waves decrease, with a resulting decrease in attenuation.

The attenuation properties in rocks and soils are specified by a wide range of measures in seismology and engineering. In order to avoid confusion, it is important to present a brief definition of terms that are used and to show how they relate to each other. The most commonly used measures of attenuation are: attenuation coefficient, $\alpha$; quality factor, $\mathrm{Q}$;

and its inverse, $\mathrm{Q}^{-1}$, commonly referred to as attenuation; logarithmic decrement, $\delta$; loss tangent, $\tan \phi$; and damping coefficient, D. Leaving out small second-order corrections 
proportional to $\alpha^{2}$, the above parameters are related by

$$
\frac{1}{\mathrm{Q}}=\frac{\alpha \mathrm{V}}{\pi \mathrm{f}}=\frac{\delta}{\pi}=\tan \phi=2 \mathrm{D}=\frac{\Delta \varepsilon}{2 \pi \varepsilon}
$$

where $V$ is wave velocity, $f$ is frequency, $\Delta \varepsilon$ is the energy loss per cycle and $\varepsilon$ is the strain energy stored in the specimen during a cycle (Toksöz and Johnston, 1981).

Significant differences in elastic moduli and wave attenuation have been observed for rocks measured with different laboratory and field techniques. These differences can be attributed to the frequency and strain amplitude dependencies in the anelastic response of rock to loading. Anelastic mechanisms in rock produce a phase lag between stress and strain and affect the measured moduli and attenuation. The modulus, $M$, is represented by a complex quantity,

$$
M=M_{R}+i M_{I}
$$

where $M_{R}$ and $M_{I}$ are the real and imaginary parts of the modulus, respectively. The phase lag, $\phi$, is a direct measure of the intrinsic loss or attenuation, $Q^{-1}$ (Toksöz and Johnston, 1981),

$$
\mathrm{Q}^{-1}=\mathrm{M}_{\mathrm{I}} / \mathrm{M}_{\mathrm{R}}=\tan \phi
$$

Previous studies have reported frequency, strain amplitude, and saturation dependencies on elastic moduli and $\mathrm{Q}^{-1}$ in many types of crustal rocks (Gordon and Davis, 1968; Toksöz et al., 1979; Winkler et al., 1979; Spencer, 1981; Dunn, 1986; Paffenholz and Burkhardt, 1989). A variety of laboratory techniques were used for these measurements; the method used depends on the frequency of interest. Other factors such as rock porosity, pore geometry, and pore fluid pressure also influence the elastic and anelastic rock properties.

Spencer (1981) used a cyclic loading technique to examine the effect of frequency and fluid saturation on the modulus and attenuation for Spergen Limestone, Navajo Sandstone, and Oklahoma Granite. For dry rocks, the modulus and attenuation were independent of frequency. When the specimens were saturated with water, the modulus decreased and a frequency dependence was observed. For example at $10 \mathrm{~Hz}$, Young's modulus of the sandstone, decreased by $56 \%$ due to saturation. There was a small increase in modulus with increasing frequency between 10 and $5 \times 10^{2} \mathrm{~Hz}$. Attenuation was significantly greater for water-saturated rocks than for the dry state at all frequencies. 
Tittmann et al. (1980) and Bulau et al. (1984) used a resonant bar technique to measure modulus and $\mathrm{Q}^{-1}$ as a function of water saturation at frequencies between $10^{3}$ and $10^{4} \mathrm{~Hz}$ for a wide variety of rocks. In general, the attenuation increased and the modulus decreased as the water saturation increased.

Attenuation and elastic moduli at ultrasonic frequencies have been reported by several investigators (e.g. Toksöz et al., 1979; Coyner, 1984). These data show that Young's modulus is typically greater for water-saturated rocks than for dry rocks. Furthermore, the attenuation in dry rocks is greater than that for saturated rocks.

Strain amplitude has also been shown to affect Young's modulus and $\mathrm{Q}^{-1}$ in granite and sandstone. With increasing strain amplitude, above $10^{-7}$ or so, Young's modulus decreases and $\mathrm{Q}^{-1}$ increases (Winkler et al., 1979; Johnston and Toksöz, 1981; Bulau et al., 1984). The increase is more pronounced at higher strain amplitudes. The effect has been observed for both dry and saturated conditions.

\subsection{EXPERIMENTAL PROCEDURE}

Young's modulus and extensional attenuation have been determined as functions of frequency, strain amplitude, and water saturation for eleven tuff samples recovered from boreholes and an outcrop on or near Yucca Mountain, Nevada. A map showing the location of the boreholes on Yucca Mountain is given in Figure 1. The geological stratigraphy for the tuffs at Yucca Mountain is presented in Figure 2. Oritz et al (1985) proposed a thermal/mechanical stratigraphy based on the physical properties of the tuffs. A correlation between the thermal/mechanical units and the geological stratigraphy is also shown in Figure 2.

The samples recovered from the boreholes and prepared for testing in this study are listed in Table 1. Four techniques were used to cover frequencies ranging from $10^{-2}$ to $10^{6} \mathrm{~Hz}$. The strain amplitude dependence was measured at a single frequency, using a cyclic loading technique. Stress-strain hysteresis loops were generated at $0.1 \mathrm{~Hz}$ with peak strain amplitudes that ranged from $10^{-7}$ to $10^{-4}$. The methods along with the corresponding sample size are given in Table 2 .

The measurements were carried out under room-dry and fully water-saturated conditions. The sequence of measurements began with the cyclic loading experiments. The samples were then subdivided into smaller specimens for the waveform inversion, resonant bar, and ultrasonic velocity measurements. 


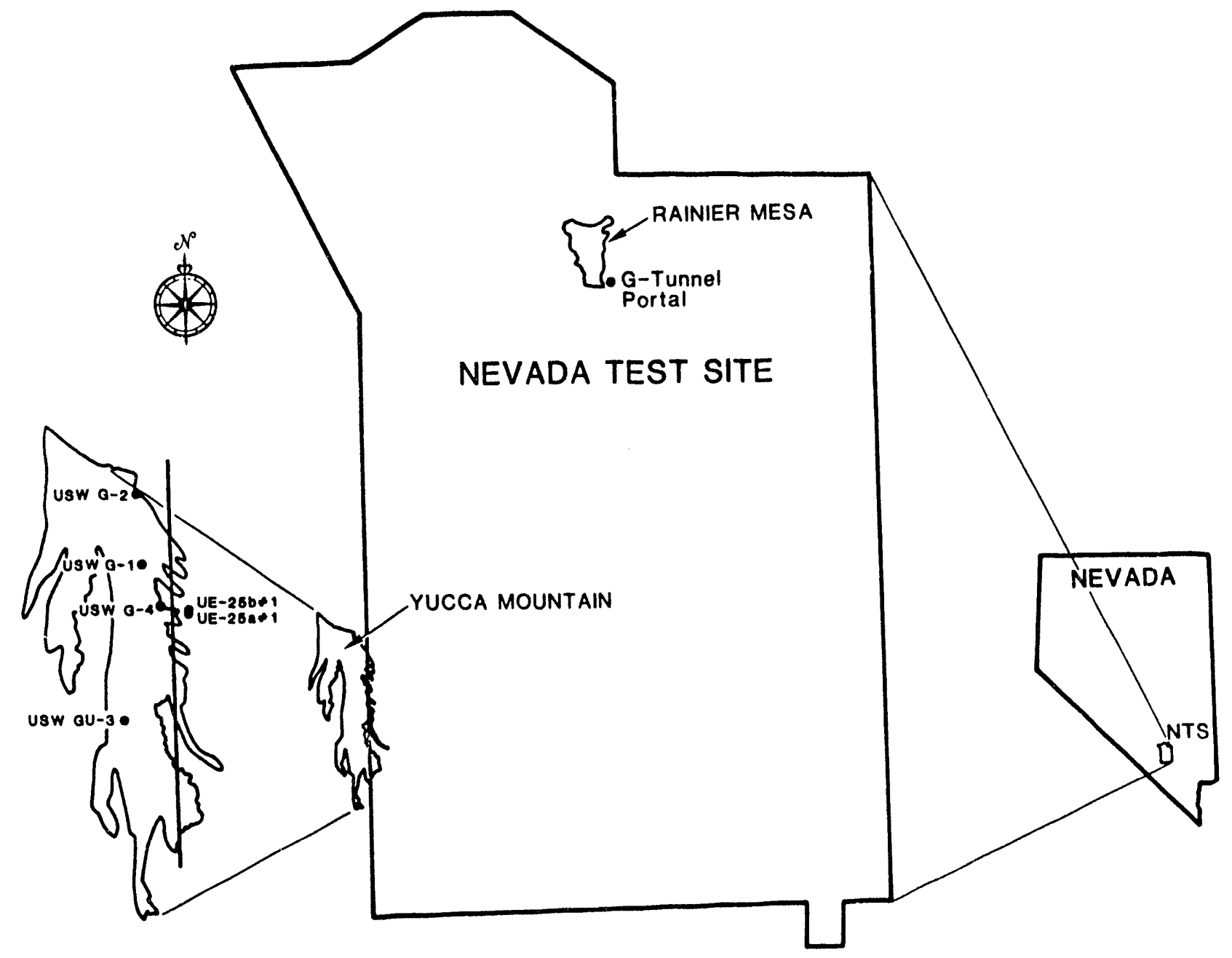

Figure 1: A map showing the Nevada test site and the relationship of Yucca Mountain with respect to the Nevada test site. 


\section{Table 1}

Tuff Samples from Yucca Mountain: Modulus and Attenuation Measurements

Ulurasonic Experiments

Formation

Borehole

depth, $\mathrm{ft}$

Tiva Canyon

Tiva Canyon

Paintbrush tuff

Paintbrush tuff

Topopah Spring

Topopah Spring

Topopah Spring

Topopah Spring

Topopah Spring

Calico Hills

Calico Hills

Topopah Spring
GU3-211.3

GU3-165.35

G4-135.0

G2-709.7

G1-409.9

G1-396.0

G1-1157.5

G1-906.0

G1-721.4

G4-1617.75

G1-1406.3

Busted Butte
Thermal/Mechanical Unit

$\mathrm{TCw}$

$\mathrm{TCw}$

PTn

PTn

TSw 1

TSw 1

TSw2

TSw2

TSw2

$\mathrm{CHn} 1 \mathrm{z}$

CHnlz

TSw2

$\underline{\text { Resonant Bar Experiments }}$

Tiva Canyon

Paintbrush Tuff

Topopah Spring
GU3-165.35

G4-135.0

Busted Butte
$\mathrm{TCw}$

PTn

TSw2

Cyclic Loading Experiments

Tiva Canyon

Topopah Spring

Calico Hills

Topopah Spring
Gu3-211.3

G1-409.9

G4-1617.75

Busted Butte
$\mathrm{TCw}$

TSw1

CHn1z

TSw2 
Table 2.

Technique and Sample Dimensions

\begin{tabular}{|c|c|c|c|}
\hline \multirow[t]{2}{*}{ Technique } & \multirow[t]{2}{*}{ Frequency } & \multicolumn{2}{|c|}{$\begin{array}{c}\text { Nominal } \\
\text { Sample dimensions }(\mathrm{mm})\end{array}$} \\
\hline & & length & diameter \\
\hline Cyclic loading & $0.01-100 \mathrm{~Hz}$ & 210 & 55 \\
\hline Waveform inversion & $1-200 \mathrm{kHz}$ & 40 & 15 \\
\hline Resonant bar & $1-200 \mathrm{kHz}$ & 201 & 13 \\
\hline Ultrasonic velocity & $700 \mathrm{kHz}$ & 25 & 25 \\
\hline
\end{tabular}

The quality and quantity of the rock determined the extent of the measurements on each lithology. Ultrasonic measurements were performed on all the specimens. The other techniques require larger specimens. It was not always possible to prepare cores of the appropriate dimensions; one sample of Topopah Spring Member (TSw2) tuff (BB-10AE67-SNL-A) had sufficient material for all four techniques on both dry-and water-saturated specimens.

Specimens used for the cyclic loading, waveform inversion, and ultrasonic velocity measurements were right circular cylinders. The ends of all specimens were ground parallel to better than $5 \times 10^{-4} \mathrm{~mm} / \mathrm{mm}$. The specimens for the resonant bar measurements were either slender rods $200 \mathrm{~mm}$ in length and $10 \mathrm{~mm}$ in diameter (GU3-165.35-SNL-B-2 and G4-135.0-SNL-B-1) or a bar $201 \mathrm{~mm}$ in length and $13 \mathrm{~mm}$ on a side (BB-10-AE-67SNL-A). The specimen with a square cross section was first cut with a diamond saw to its approximate size and then ground to the final dimensions.

Prior to the deformation measurements, the dry bulk density and average grain density of each sample were measured. The grain densities were determined using a Micrometrics gas pycnometer. The porosities were computed from these data. 


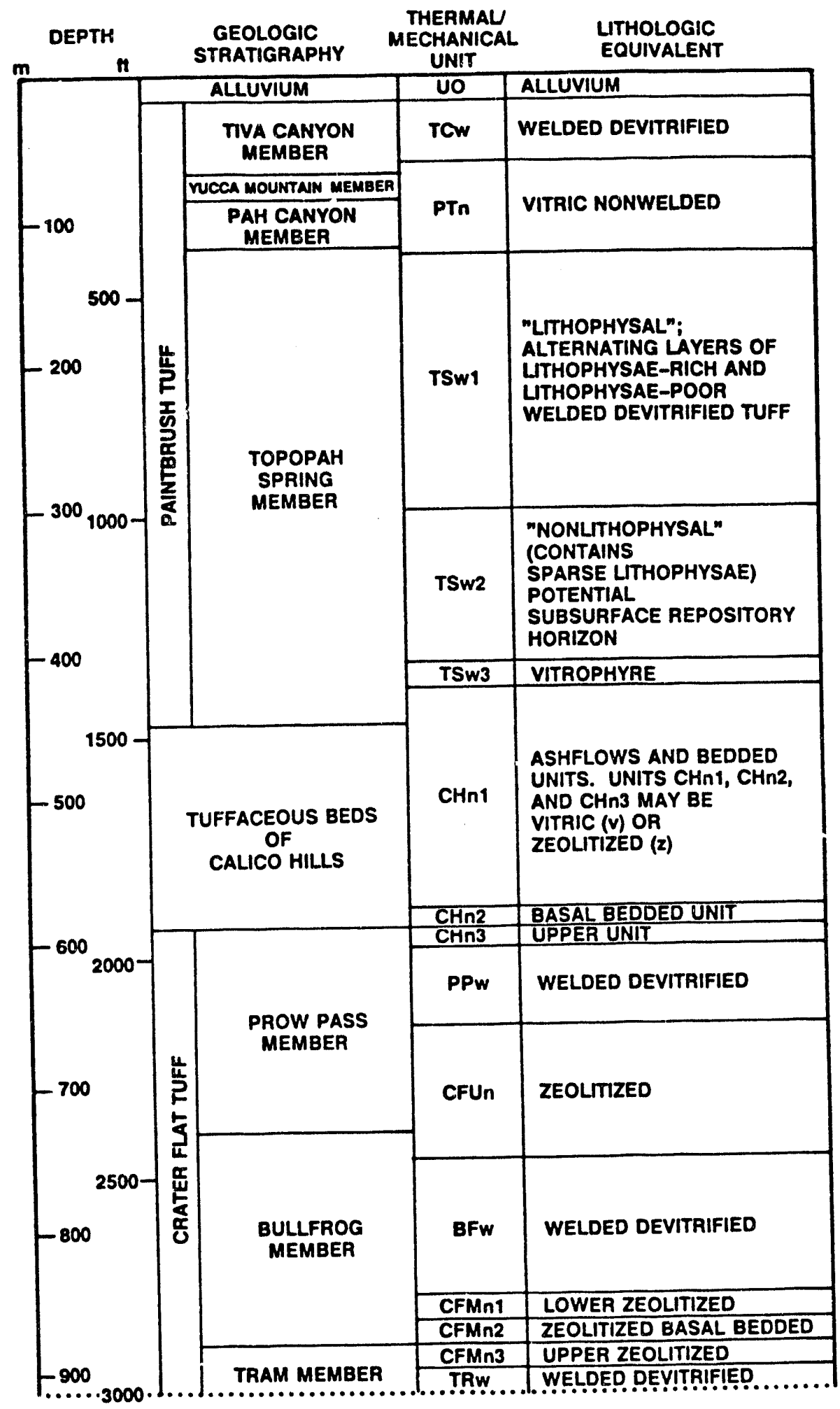

Figure 2: Comparison of geologic and thermal/mechanical stratigraphies of Yucca Mountain. 


\subsection{Crclic Loading Experiments}

A cyclic loading technique was used to investigate attenuation in the tuffs at low frequency and moderate to high strain amplitudes. In this technique, the sample is subjected to a continuous sinusoidal axial force while force and displacement are measured simultaneously.

Axial displacement of the specimen was measured with three LVDT displacement transducers mounted on two rings positioned near each end of the sample. The LVDT barrels were mounted in one ring, and the LVDT cores were attached to extension rods connected to the second ring. The axial displacement was the average of the three LVDTs. This sample assembly was positioned in series with a load cell in a hydraulic, servocontrolled loading frame. The sample was exposed to the atmosphere at room temperature and initially loaded to approximately $1 \mathrm{MPa}$. The specimen was loaded with a compressional sinusoidal axial force at frequencies between $10^{-2}$ and $10^{2} \mathrm{~Hz}$. A function generator provided a reference signal for the system. Axial force from the load cell and sample displacement from the three LVDT transducers were measured and recorded with the PC-based data acquisition system.

Measurements were made at strain amplitudes between $10^{-6}$ and $10^{-4}$. At each strain amplitude, the data were collected for 1 to 200 cycles. The strain was computed by dividing the displacement by the distance between the centers of the two mounting rings. Axial stress was calculated by dividing the measured load by the sample cross-sectional area.

Young's modulus and $\mathrm{Q}_{\mathrm{E}}^{-1}$ were determined from the fast Fourier transforms of the stress and strain sinusoids. The modulus was caiculated from the ratio of the peak amplitudes for the stress and strain spectrums at the driving frequency. $\mathrm{Q}_{\mathrm{E}}{ }^{-1}$ was computed in the frequency domain from the complex Young's modulus as given in Equation 3. Mechanical and electronic system losses were determined by conducting identical tests on a low loss standard (aluminum) with the same cross-sectional area and length as the rock specimens.

\subsection{Wayeform Inversion}

Elastic wave velocities and attenuations were determined jointly for frequencies ranging from $10^{3}$ to $2 \times 10^{5} \mathrm{~Hz}$ by using a waveform inversion technique based on the theory of 
low-frequency wave propagation along an elastic cylinder. This technique (Tang, 1992) compares the waveshapes obtained from measurements on two samples of the same material but having different lengths (which can be the same physical specimen, shortened for the second measurements). Using the low-frequency theory, we then estimated the elastic speeds and attenuation which most nearly account for the difference between the two waveforms. The waveform inversion technique was used only on dry and saturated specimens of the Topopah Spring Member (TSw2) tuff.

\subsection{Resonant Bar Experiments}

Benchtop resonant bar experiments were performed on three specimens of tuff, approximately $200 \mathrm{~mm}$ in length and $10 \mathrm{~mm}$ in diameter (Table 1), fully exposed to the atmosphere, and not previously dried. One specimen of TSw2 (BB-10AE-67-SNL-A) was also tested fully saturated. The saturated sample was wrapped with teflon tape to minimize evaporation losses.

The extensional resonance modes of the sample were excited with compressional piezoelectric ceramic crystals $\left(10^{6} \mathrm{~Hz}\right)$ epoxied to both sample ends (Figure 3$)$. One crystal was arbitrarily identified as the excitation source and the other as the receiver. The sample was suspended in air with a fine thread attached to the sample at its midpoint. A phase lock amplifier was used to resonate the rod. Both source and sensing piezoelectric crystals were wired to the amplifier, one to the reference output and the second to the differential amplifier input. The differential amplifier input from the sensing crystal was able to "lock in" to the phase-shifted sine wave frequency being used to resonate the rod. A PC-controlled D/A converter was used as an external control for the phase lock amplifier reference sine wave output to sweep the frequency band of interest the amplified signal from the sensing crystal was measured as a function of frequency. Extensional wave attenuation was calculated by dividing frequency range at the half-power level $(3 \mathrm{~dB}$ lower than resonance amplitude), $\Delta f$, by the center frequency, $f_{c}$.

$$
\mathrm{Q}_{\mathrm{E}}^{-1}=\Delta \mathbf{f} / \mathbf{f}_{\mathbf{c}}
$$

Extensional (bar) velocity, $\mathrm{V}_{\mathrm{E}}$, was calculated by dividing the wavelength of the fundamental mode, which is twice the sample length, by the center frequency.

The extensional wave velocity is typically lower than the compressional wave velocity. The boundary conditions for a propagating wave in a long bar with free surfaces produce a 


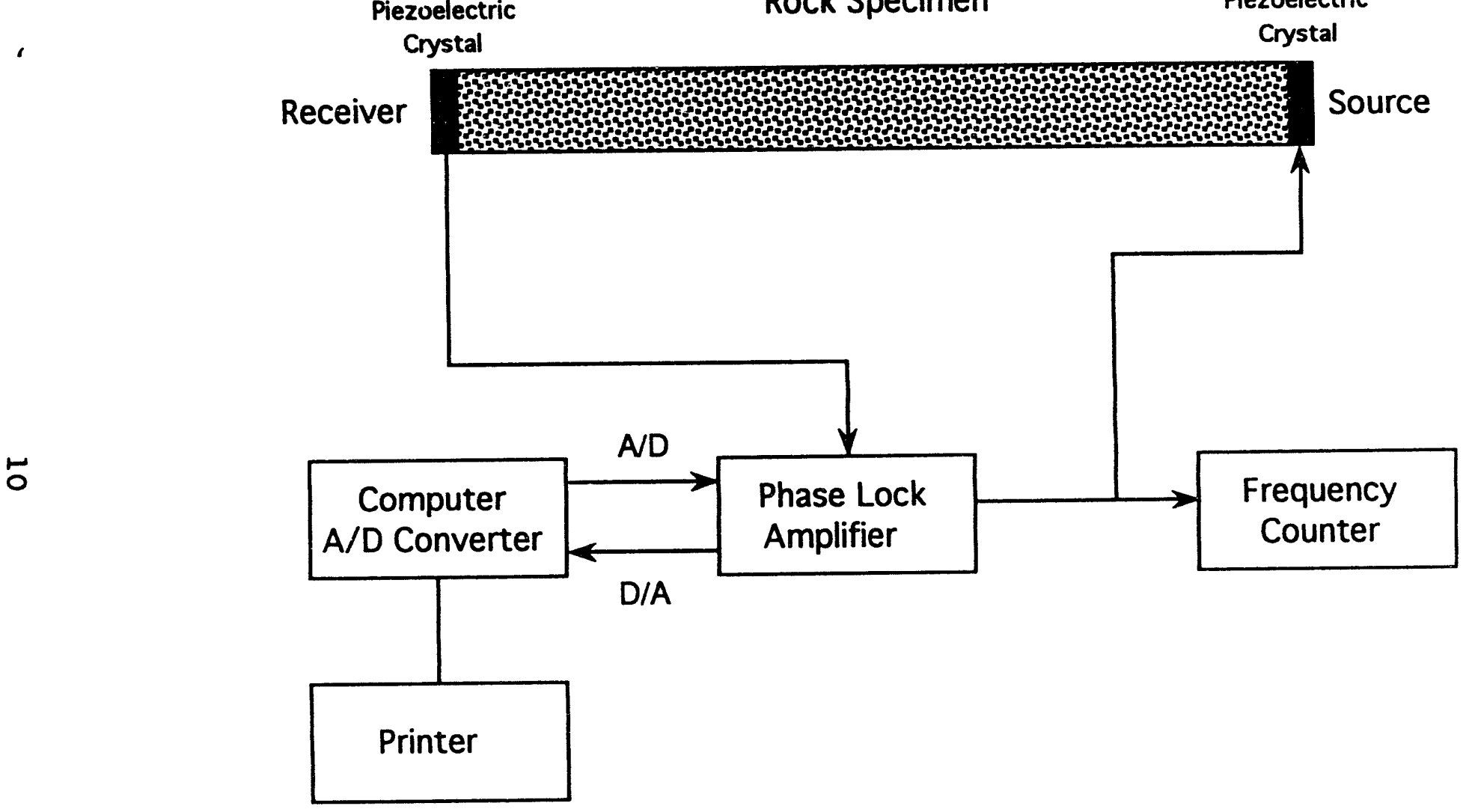

Figure 3: Schematic diagram of the benchtop resonant bar apparatus. 
wave travelling at a lower velocity. The relationship between the compressional (longitudinal), $\mathrm{V}_{\mathrm{p}}$; shear, $\mathrm{V}_{\mathrm{s}}$; and extensional (bar) wave velocity, $\mathrm{V}_{\mathrm{E}_{j}}$ is

$$
V_{E}=\left[V_{s}^{2}\left(3 V_{p}^{2}-4 V_{s}^{2}\right) /\left(V_{p}^{2}-V_{s}^{2}\right)\right]^{0.5}
$$

Young's modulus, $E$, was calculated from

$$
E=\rho V_{E}^{2}
$$

where $\rho$ is the density of the specimen.

The mass of the piezoelectric crystals and sample jacket were accounted for in a correction factor described by Lucet et al. (1991). Tittmann et al. (1980) and Lucet et al. (1991) discussed this technique in detail.

\subsection{Ultrasonic Experiments}

Ultrasonic velocity and attenuation measurements were performed on the thirteen samples of tuff. Broadband compressional (P) and shear (S) wave pulses, with maximum spectral amplitudes between 600 and $1200 \mathrm{kHz}$, were propagated through specimens nominally $25 \mathrm{~mm}$ in length by $25 \mathrm{~mm}$ in diameter. Measurements were carried out as a function of confining pressure for both room dry and saturated conditions at ambient laboratory temperatures (about $22^{\circ} \mathrm{C}$ ). Velocities were calculated from the transit time of first arrivals. Attenuations were calculated with a spectral ratio technique (Toksöz et al., 1979) using 6061 aluminum as a high $Q$ standard.

The apparatus used in the experiments included a source and receiver pair of like transducers ( $\mathrm{P}, \mathrm{S1}$, or $\mathrm{S2}$ ), a pulse generator, an amplifier, a filter, and a digital oscilloscope (Figure 4). The source crystal was excited by a fast risetime electrical pulse generated with a pulser-receiver. The crystal produced a broadband ultrasonic pulse that propagated through the adjacent titanium plate, through the rock sample along the core axis, through the titanium plate at the opposite end of the core, and into the receiver crystal. The electrical signal produced by the receiver transducer was amplified and filtered by the receiving section of the pulser-receiver, then digitized by an oscilloscope. The signals were typically amplified by 20 to $40 \mathrm{~dB}$ and high-pass filtered above $0.3 \mathrm{MHz}$. The oscilloscope displayed the signal for a travel time pick and the digitized signal was transferred to a computer for subsequent spectral attenuation analysis.

In a typical ultrasonic experiment, the sample is positioned between the source and receiver transducers, jacketed with polyolefin shrink tubing, and placed in a pressure vessel. A thin film of viscous resin couples the transducers to the sample for maximum 


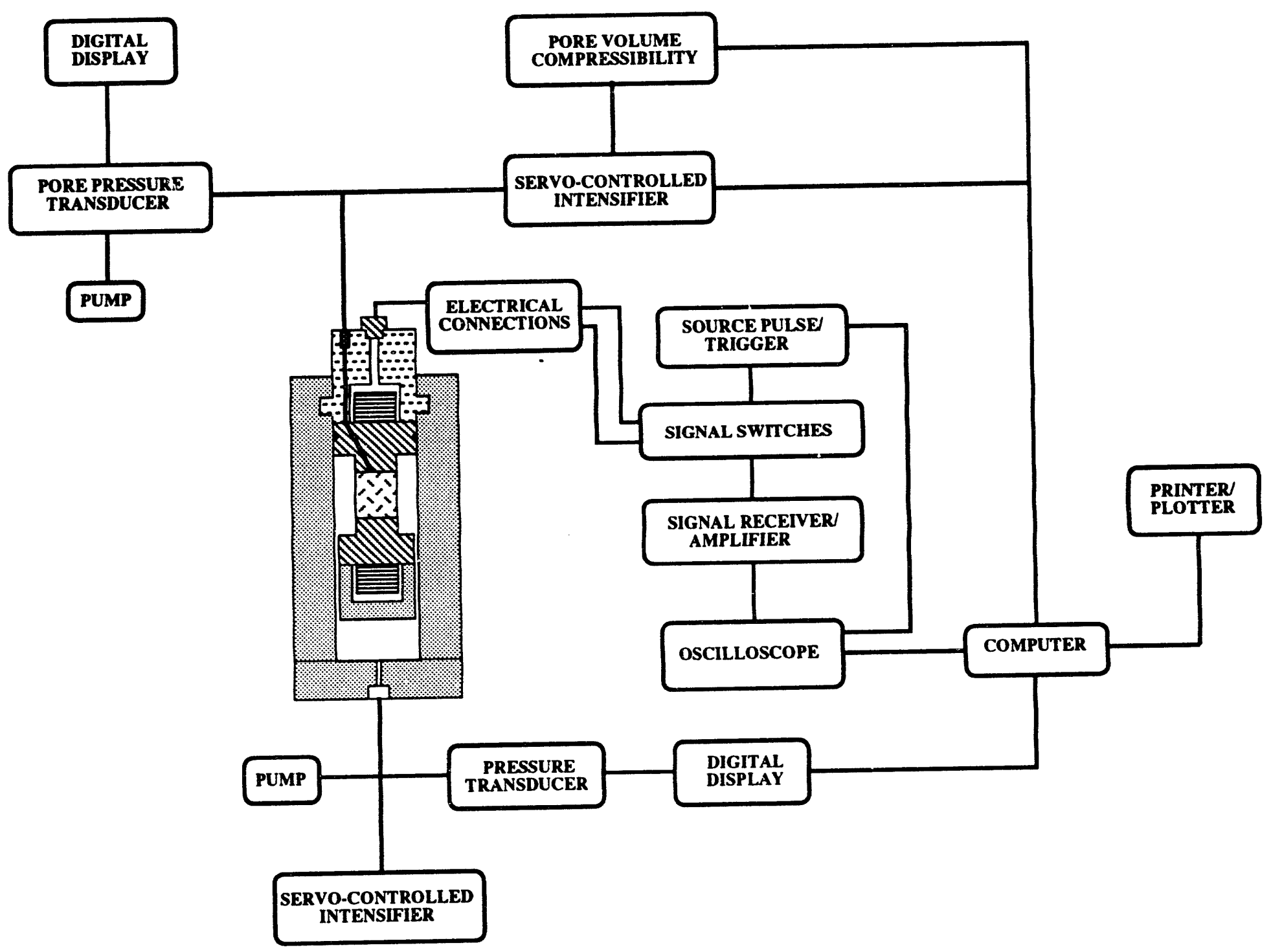

Figure 4: Schematic diagram of the experimental apparatus for ultrasonic velocity and attenuation measurements under pressure. 
transmission of signals. The room dry measurements were always conducted first. The confining pressure was applied to the sample assembly and allowed to equilibrate for a period of approximately 10 minutes. Sequential P, S1, and S2 wave signals were propagated through the sample from source to receiver. Signals were displayed on the oscilloscope, travel times were picked, and the digitized signals were saved. Travel times were picked, with 10-nanosecond resolution, where a threshold voltage equal to $1.25 \%$ of the overall peak-to-peak amplitude of the received signal was exceeded. The entire sequence was repeated at successively higher confining pressures: 1.0, 2.5, 5.0, 7.5, 10.0 , and $15.0 \mathrm{MPa}$.

After the dry measurements, the sample assembly was removed from the pressure vessel and the specimen was saturated with water. The saturated specimen was carefully jacketed and located between the transducers so as not to entrap any air, and the sample assembly was placed into the pressure vessel. Pore fluid pressure was externally controlled through a small port in one of the transducers. The first set of confining and pore fluid pressures, 3.5 $\mathrm{MPa}$ and $2.5 \mathrm{MPa}$, respectively, were applied to the specimen and allowed to equilibrate for a period of approximately 10 minutes. Ultrasonic measurements were then made in the same manner as for the dry samples. The sequence of confining pressures was $3.5,5.0,7.5,10.0,12.5$, and $17.5 \mathrm{MPa}$. A constant pore pressure of 2.5 $\mathrm{MPa}$ was maintained. The effective confining pressure (confining pressure minus pore fluid pressure) was the same for both dry and saturated measurements.

Velocity and attenuation values for both $\mathrm{P}$ and $\mathrm{S}$ waves were calculated for the rock specimens at each confining pressure. Velocity was calculated by dividing specimen length by travel time through the rock. Specimen lengths were not corrected for strain under pressure because the resultant error in sample length was always less than $0.1 \%$. Travel time through the sample was calculated by subtracting travel time through the titanium end pieces, from the total travel time.

Seismic attenuation was calculated using a spectral ratio technique. Two signals were recorded with the equipment settings exactly the same, one through the rock and the second through an aluminum standard of the same size. The digitized signals were displayed and windowed in the time domain over approximately two full cycles. The window edges were smoothed with a cosine taper. The two windowed signals were decomposed into amplitude versus frequency data utilizing standard Fourier analysis. The individual amplitude data and the natural logarithm of the ratio between them were displayed as functions of frequency. A least squares fit of the slope was made over a frequency band defined by $50 \%$ cutoffs of the peak signal amplitude in the frequency domain. The 
attenuation is given by

$$
\mathrm{Q}^{1}=\frac{\gamma \mathrm{V}}{\pi}
$$

where $\mathrm{V}$ is the measured velocity, and

$$
\gamma=\ln \left(\frac{A_{1}}{A_{2}}\right)
$$

where $A_{1}$ and $A_{2}$ are the spectral amplitudes for the aluminum standard and the rock respectively (Toksöz et al., 1979).

This method of measuring and calculating attenuation incorporates several assumptions. Attenuation is assumed to be constant over the frequency band of the signal, geometrical factors such as spreading and reflections are assumed constant for the two signals, and attenuation of the aluminum is assumed to be very small relative to the rock. The important variables in applying the technique included variations in window lengths, both in the time domain over which the ultrasonic signal was selected and in the frequency domain over which the spectral ratio slope was taken. The spectral ratio slope was normally well defined, although to a large extent this was achieved by interactively adjusting window lengths. A conservative estimate of error inherent in applying the technique is $\pm 25 \%$.

\subsection{EXPERIMENTAL RESULTS}

One sample of Topopah Spring Member (TSw2) tuff, from a Busted Butte outcrop (BB-10-AE-67-SNL-A), was studied thoroughly. This was due to better sample availability, improved experimental technique as the project progressed, and the importance of the TSw2 as the potential repository rock. In light of the completeness of the data set and because it is the only rock on which all four experimental methods were performed, the results on these specimens are discussed separately.

The effect of frequency on Young's modulus and attenuation for the other tuff specimens is not as comprehensive. The data obtained on these rocks will be presented in terms of the experimental technique used to acquire the data. 
Outcrop Sample - Topopah Spring Member Tuff

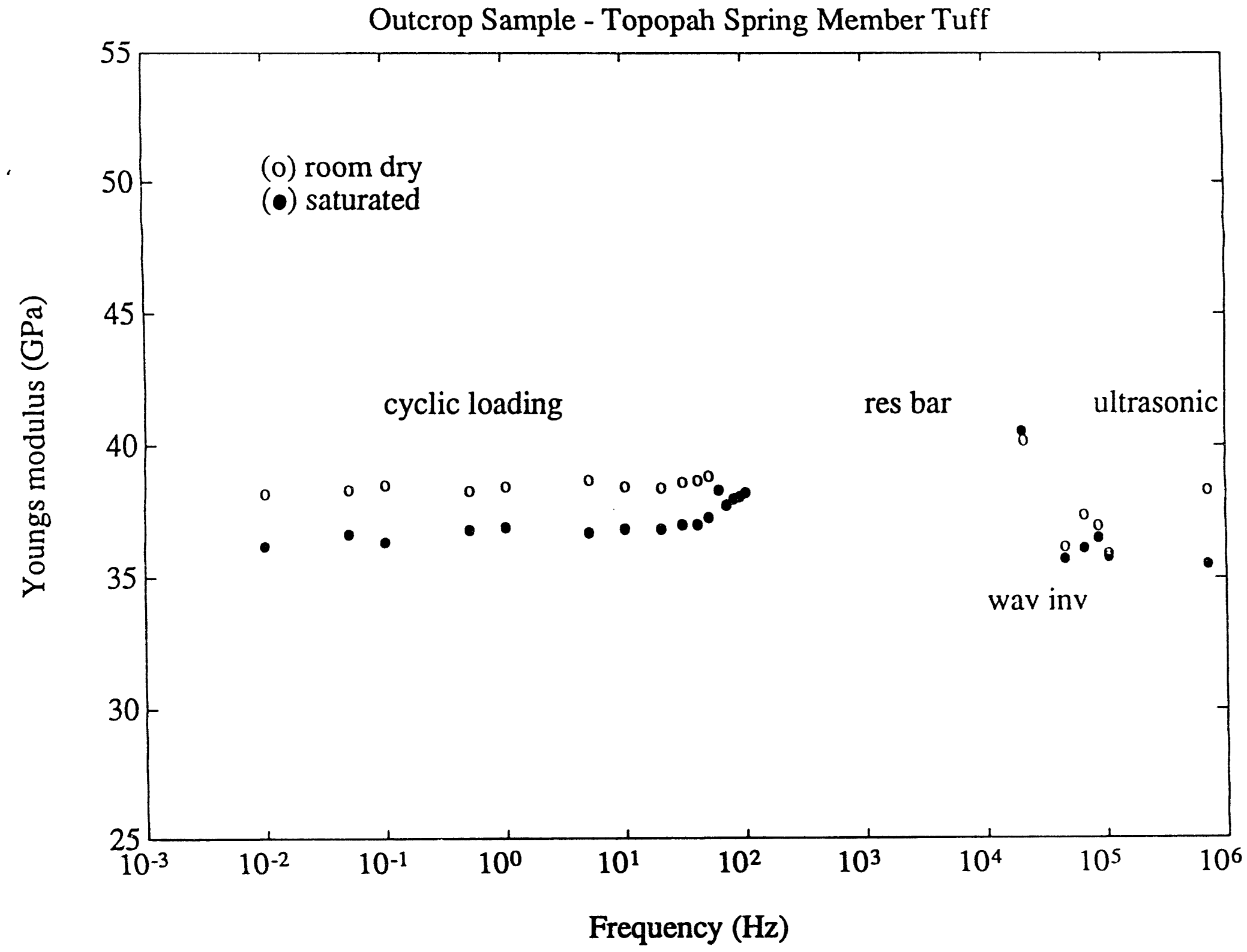

Figure 5: Young's modulus is shown as a function of frequency for a specimen of Topopah Spring Member tuff (TSw2) from the Busted Butte outcrop. All the measurements were performed at atmospheric pressure for dry and water saturated conditions. 
Busted Butte - 10AE -67-SNL-A
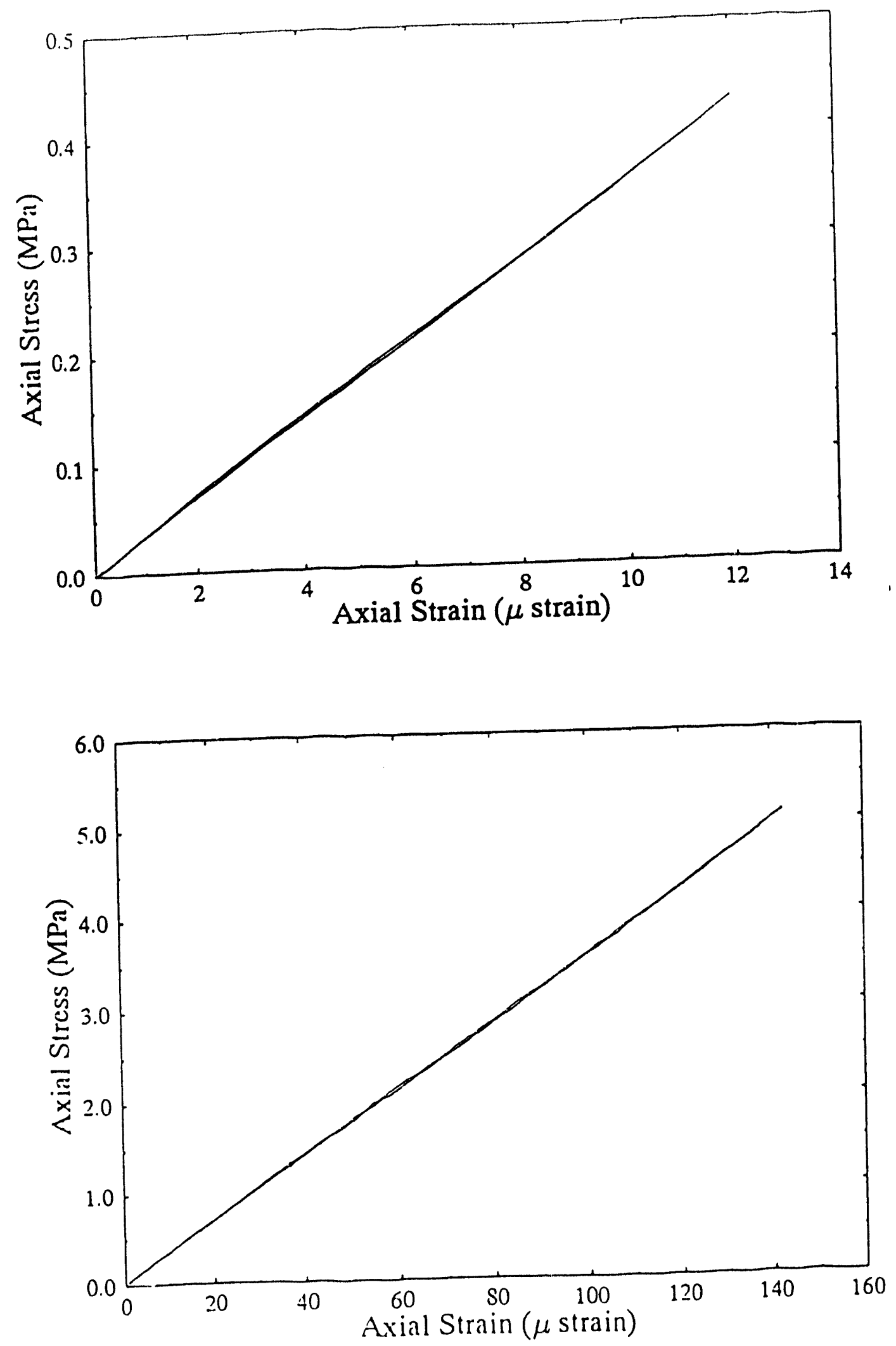

Figure 6: Axial stress is plotted as a function of axial strain for two cyclic loading experiments on a specimen of Topopah Spring Member tuff (TSw2) from the Busted Butte outcrop. The measurements were performed on a dry specimen at atmospheric pressure. 
We11: $B B-10 A E-67-S N L$ Sample: TUFF DRY Conf Pr: $79.00 \mathrm{psi}$

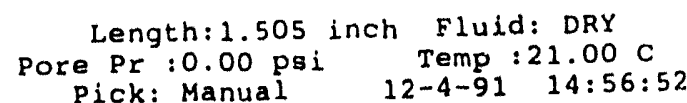
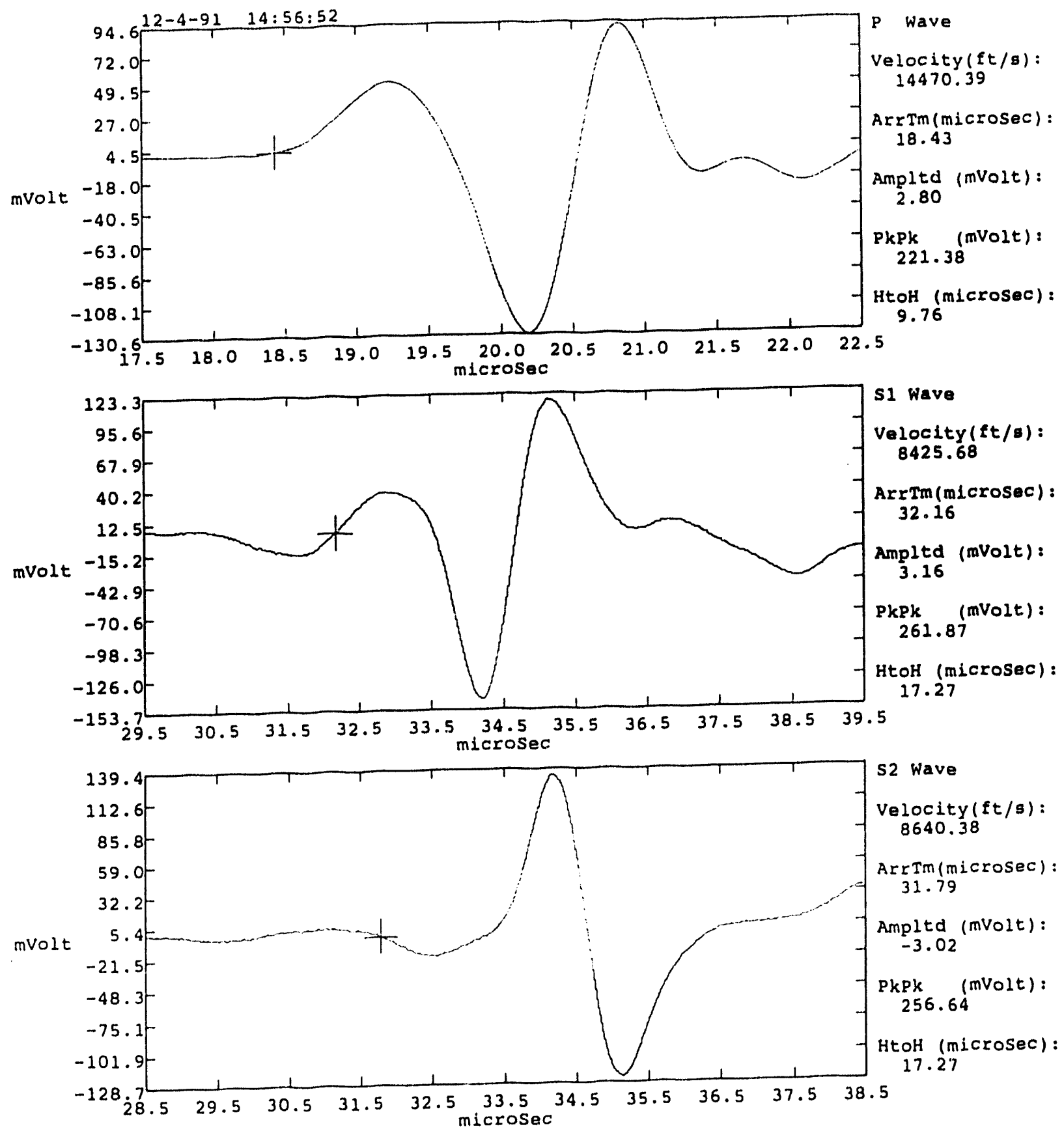

Figure 7: Compressional and shear wave time series plots for a specimen of Topopah Spring Member tuff (TSw2) from the Busted Butte outcrop. The measurements were obtained in a bench top apparatus under atmospheric conditions on a dry specimen. 


\subsection{Topopah_Spring Member Turf/Busted Butte Outcron}

The effects of frequency on Young's modulus for room-dry and water-saturated tuff are shown in Figure 5. Young's modulus for the dry tuff exhibits a small dependency on frequency between $10^{-2}$ and $10^{6} \mathrm{~Hz}$. The cyclic loading measurements yielded a modulus of $38.2 \mathrm{GPa}$ at $10^{-2} \mathrm{~Hz}$. Young's modulus increased less than $2 \%$ as the frequency was increased to $50 \mathrm{~Hz}$. Typical stress-strain curves for these measurements are shown in Figure 6. Axial stress is plotted as a function of axial strain for two strain amplitudes, 12 and 140 microstrain. An initial pre-load of $1 \mathrm{MPa}$ was applied to the specimen prior to the cyclic loading measurements.

The modulus computed from the compressional and shear wave velocities is $38.3 \mathrm{GPa}$. This is in excellent agreement with the lower-frequency, cyclic loading measurements. The velocity data was collected in a benchtop apparatus with an applied stress of $1 \mathrm{MPa}$ parallel to the wave propagation direction. Waveforms obtained for the tuff are shown in Figure 7. Three time series are shown; the top waveform is the compressional wave and the two lower waveforms are from the orthogonally polarized shear waves (S1 and S2).

The moduli computed using the resonant bar and waveform inversion techniques at about the same frequencies differ. For dry specimens, the Young's modulus computed from the first mode of the resonant bar measurements was $40.2 \mathrm{GPa}$ at $20 \mathrm{kHz}$, whereas the waveform inversion method yielded a value of $36.2 \mathrm{GPa}$ at $45 \mathrm{kHz}$.

The modulus for the water-saturated tuff was lower than the corresponding dry value at the same frequency by approximately $5 \%$, except for the resonant bar where the modulus for the saturated specimen was $1 \%$ larger than for the dry condition. The values computed from the cyclic loading data exhibit noticeable dispersion at frequencies between 50 and $100 \mathrm{~Hz}$. The effect of saturation on the moduli measured with the resonant bar and waveform inversion technique was smali. For each technique, water saturation reduced the modulus.

$\mathrm{Q}_{\mathrm{E}}{ }^{-1}$ is shown as a function of frequency in Figure 8. For the dry condition, $\mathrm{Q}_{\mathrm{E}}^{-1}$ is relatively low and independent of frequency below $50 \mathrm{~Hz}$. The resonant bar attenuations, about $2.3 \times 10^{-3}$, are essentially the same as the cyclic loading measurements, 0.1 to $3.7 \times 10^{-3}$. The waveform inversion and the ultrasonic techniques yielded higher attenuations, averaging $19.5 \times 10^{-3}$ and $23.5 \times 10^{-3}$, respectively.

The $Q_{E}{ }^{-1}$ in dry tuff was lower than that for the saturated conditions at corresponding frequencies. At frequencies below $10 \mathrm{~Hz}$, the attenuation for the saturated state was 
Outcrop Sample - Topopah Spring Member Tuff

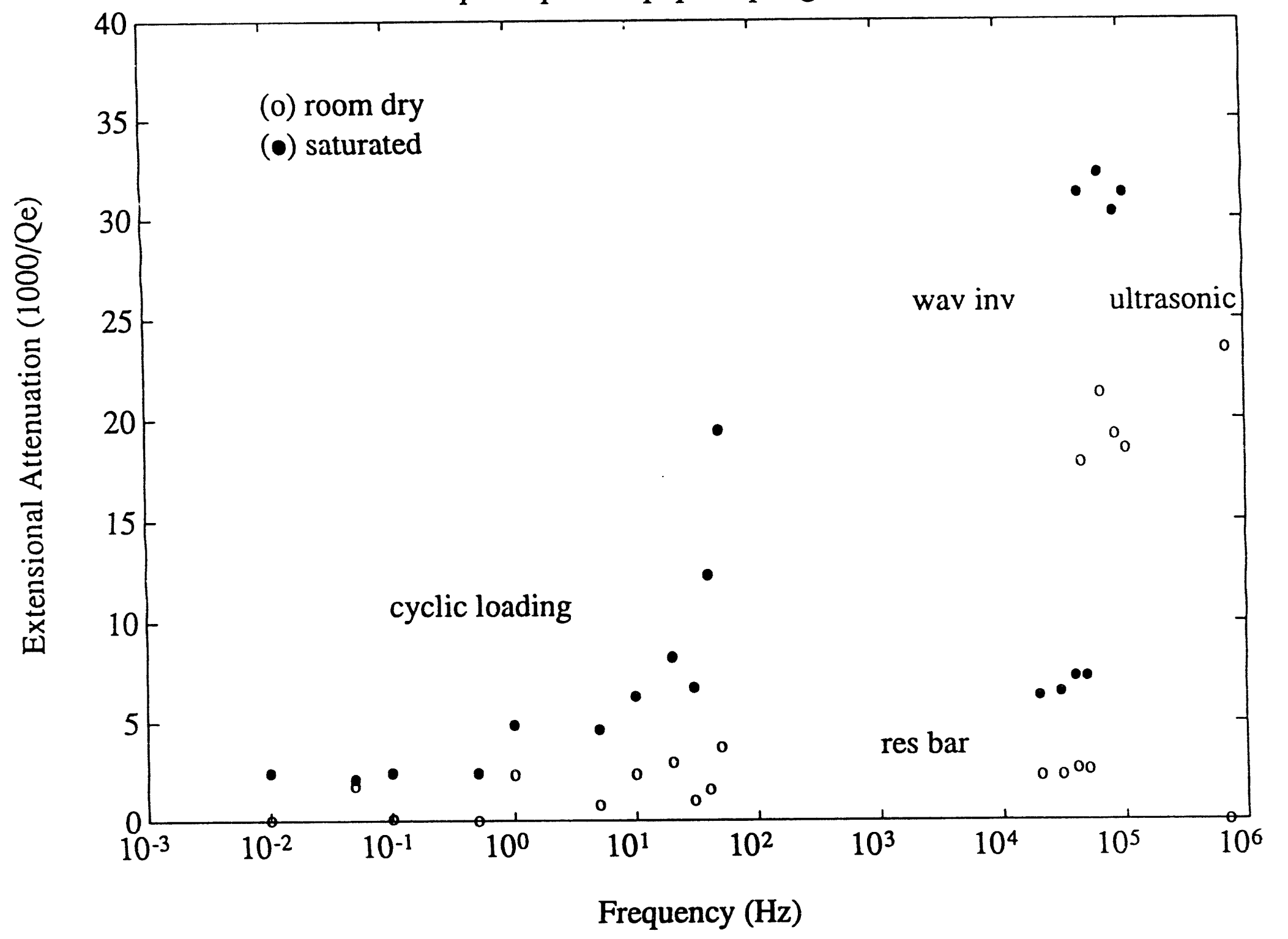

Figure 8: The attenuation for a specimen of Topopah Spring Member tuff (TSw2) from the Busted Butte outcrop is shown as a function of frequency. The measurements were carried out under atmospheric pressure. Data are shown for both dry and saturated states. 
$3.2 \pm 1.7 \times 10^{-3}$. Between 10 and $10^{2} \mathrm{~Hz}$, the attenuation increased six-fold. A large difference between the attenuations measured with the waveform inversion and resonant bar methods was observed; the attenuations for the two methods at $5 \times 10^{4} \mathrm{~Hz}$ differed by a factor of five. No attenuation was calculated with the ultrasonic data from the saturated sample because of poor signal quality.

\subsection{Partial Data_Sets}

\subsubsection{Cyclic Loading}

Cyclic loading experiments were performed on specimens of TCw, TSw1, TSw2, and $\mathrm{CHn} 1$ at atmospheric pressure, room temperature, at a frequency of $10^{-1} \mathrm{~Hz}$. The results of these measurements are presented in Table 3. As an integral part of the cyclic loading experiments, the effect of strain amplitude was measured; typically strain amplitudes ranged from $5 \times 10^{-7}$ to $8 \times 10^{-5}$. Figures $9 \mathrm{a}$ and $9 \mathrm{~b}$ shows the effect of strain amplitude on Young's modulus and extensional attenuation for the TSw2 specimen (BB-10AE-67SNL). This specimen was studied at both air dry and water-saturated conditions. As the strain amplitude increased, little variation in the Young's modulus was observed. Young's modulus for the dry condition exhibited a more or less constant value of $38.4 \mathrm{GPa}$ at strains between $10^{-6}$ and $10^{-4}$. Similarly, the moduli for the saturated conditions were independent of strain amplitude and exhibited values of $36.3 \mathrm{GPa}$. Attenuation for saturated specimens was generally larger than that for the dry state at corresponding strain amplitudes; however, there is an appreciable amount of scatter in the attenuation measurements. There is no consistent trend in attenuation with increasing strain amplitude for either the dry or saturated conditions.

Data from specimens of TCw, TSw1, and CHN1z are also given in Table 3. These experiments were carried out on air or room dry specimens only. The results from the Tiva Canyon ( $\mathrm{TCw}$ ) formation show that the Young's modulus decreases from 39.1 to 34.7 $\mathrm{GPa}$ as strain amplitude increased from $5 \times 10^{-7}$ to $7.6 \times 10^{6}$. Over the same range of strain amplitudes, there is more than a five-fold increase in attenuation.

For the lithophysae-rich, TSw1, the effect of strain amplitude on modulus was small. Similarly, the attenuation showed only a small increase with increasing strain amplitude. 
Table 3

Cyclic Loading measurements: Young's modulus and attenuation at $0.1 \mathrm{~Hz}$

\begin{tabular}{|c|c|c|c|c|}
\hline Unit & Sample & $\begin{array}{l}\text { Strain } \\
\text { Amplitude } \\
\text { (microstrain) }\end{array}$ & $\begin{array}{l}\text { Young's } \\
\text { Modulus } \\
\text { (GPa) }\end{array}$ & $\begin{array}{r}\text { Extensional } \\
\text { Attenuation } \\
(1000 / Q \mathrm{Q})\end{array}$ \\
\hline \multirow[t]{4}{*}{$\mathrm{TCw}$} & GU3-211.3-SNL-B & 0.5 & 39.1 & 2.8 \\
\hline & Room dry & 1.3 & 36.1 & 9.4 \\
\hline & & 3.99 & 35.3 & 10.2 \\
\hline & & 7.55 & 34.7 & 16.1 \\
\hline \multirow[t]{4}{*}{ TSw1 } & G1-409.9-SNL-B & 5.92 & 10.7 & 41.4 \\
\hline & Room dry & 12.9 & 10.5 & 46.5 \\
\hline & & 22.9 & 11.0 & 57.6 \\
\hline & & 39.2 & 11.9 & 61.2 \\
\hline \multirow[t]{5}{*}{ TSw2 } & BB-10-AE-67-SNL & 2.7 & 38.3 & 2.5 \\
\hline & Room dry & 7.3 & 38.3 & 1.7 \\
\hline & & 15.3 & 38.5 & 1.4 \\
\hline & & 53.1 & 38.4 & 2.6 \\
\hline & & 80.7 & 38.2 & 2.6 \\
\hline \multirow[t]{5}{*}{ TSw2 } & BB-10-AE-67-SNL & 6.1 & 36.0 & 4.1 \\
\hline & Water-saturated & 10.1 & 36.3 & 1.9 \\
\hline & & 17.4 & 36.2 & 3.2 \\
\hline & & 31.0 & 36.1 & 3.6 \\
\hline & & 70.3 & 36.1 & 3.1 \\
\hline \multirow[t]{3}{*}{ CHnlz } & G4-1617.5-SNL-B & 4.1 & 15.8 & 9.8 \\
\hline & Room dry & 8.6 & 15.8 & 11.1 \\
\hline & & 15.6 & 15.8 & 12.8 \\
\hline
\end{tabular}




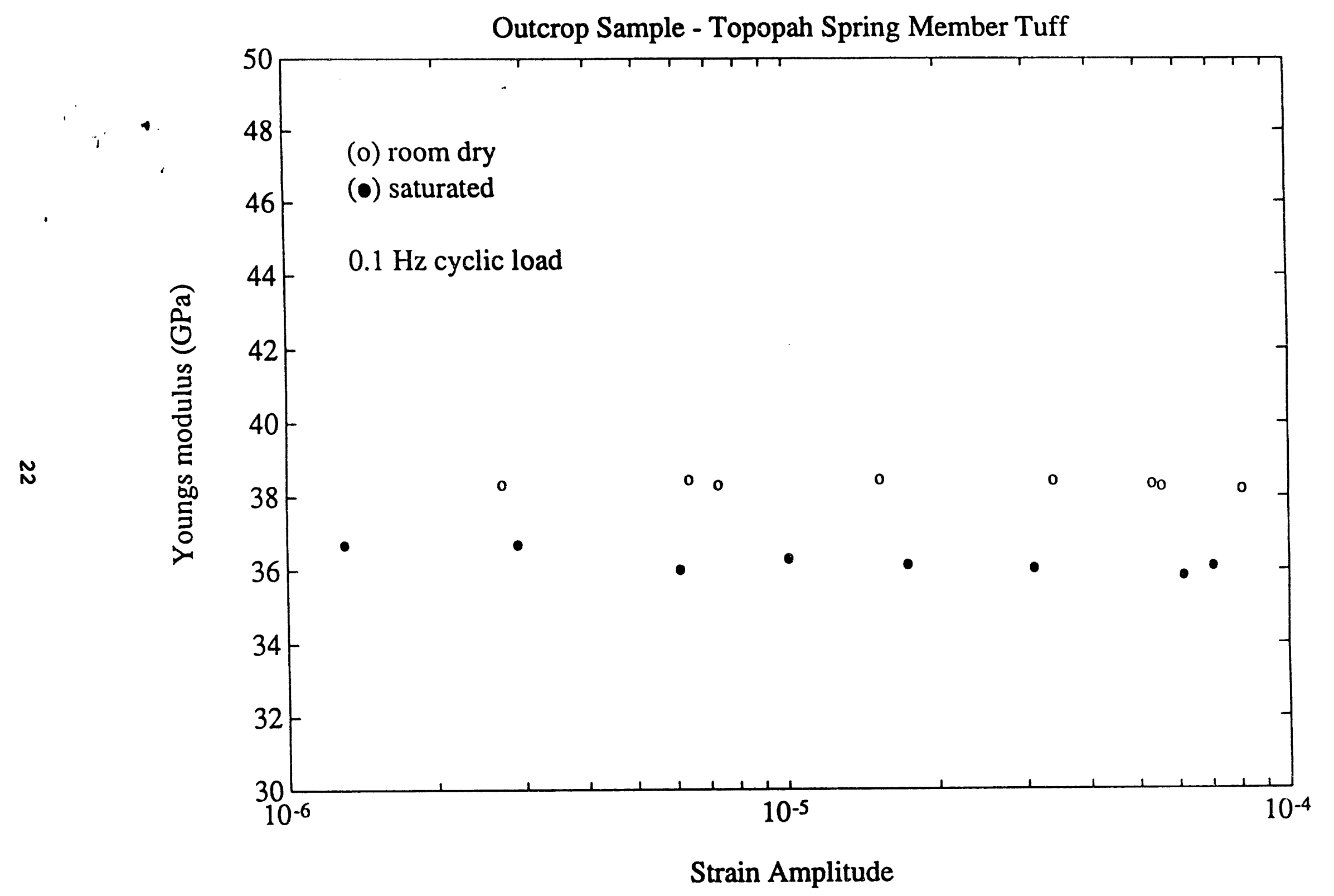

Figure 9a: Young's modulus is shown as functions of strain amplitude for a specimen of Topopah Spring Member tuff (TSw2). The data were collected on dry and saturated specimens at a frequency of $0.1 \mathrm{~Hz}$ at atmospheric pressure. 


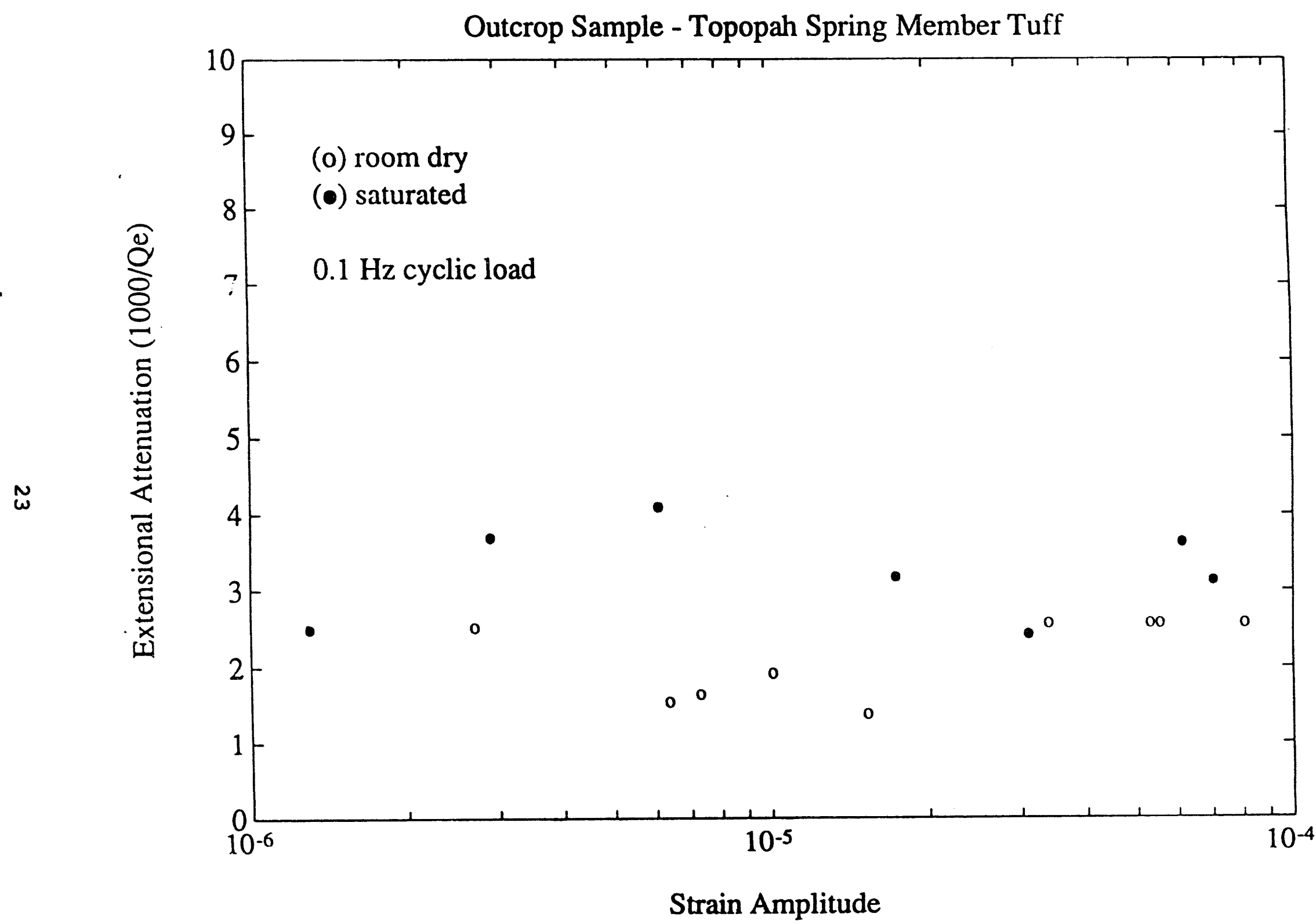

Figure 9b: Estensional attenuation is shown as functions of strain amplitude for a specimen of Topopah Spring Member tuff (TSw2). The data were collected on dry and saturated specimens at a frequency of $0.1 \mathrm{~Hz}$ at atmospheric pressure. 
The tuff from the Calico Hills formation (CHn1z) showed no strain amplitude effect on Young's modulus. The extensional attenuation, $\mathrm{Q}_{\mathrm{E}}{ }^{-1}$, increased from $9.8 \times 10^{-3}$ to $12.8 \times$ $10^{-3}$ as the strain amplitude was increased from $4 \times 10^{-6}$ to $1.6 \times 10^{-5}$.

\subsubsection{Resonant Bar}

Resonant bar measurements were carried out on three specimens: one from the Topopah Spring Member (TSw2) tuff (the specimen discussed above), and one each from the Tiva Canyon (TCw) and the nonwelded Paintbrush (PTn) tuff units. These data are summarized in Table 4.

The resonant bar data collected for the Tiva Canyon (TCw) specimen (GU3-165.35SNL-B-2) is shown in Figure 10. The amplitude of the measured signal is plotted as a function of frequency. The resonant peak was measured at $13.56 \mathrm{kHz}$. The attenuation for the specimen, computed using Equation 3, yielded a value of $1.1 \times 10^{-3}$. Young's modulus was computed as $35.7 \mathrm{GPa}$ from the extensional wave velocity measured during the experiment.

Attenuation from resonant bar data for the specimen of PTn ( G4-135.0-SNL-B), measured at a frequency of $5.28 \mathrm{kHz}$, was $5.4 \times 10^{-3}$; the corresponding Young's modulus was $6.8 \mathrm{GPa}$.

\subsection{Ultrasonic Measurements}

Much of the data for this study was collected using the ultrasonic technique. Compressional (longitudinal) and shear wave velocities were measured on each specimen as a function of confining pressure. The dry specimens were measured at pressures ranging from 1.0 to $15 \mathrm{MPa}$. In the saturated condition, velocities were determined at the same effective confining pressures, with a constant pore pressure of 2.5 MPa. Data on these specimens are given in Tables 5a through 51. In each table, the compressional and shear wave velocities are listed as a function of confining pressure. In addition, the seismic wave attenuations are presented as a function of effective confining pressure. The attenuations for the compressional and shear waves are not directly comparable to the extensional attenuations, because the extensional wave velocity is lower than compressional wave velocity. Furthermore, $Q_{S}{ }^{-1}$, the shear wave attenuation, has not been measured on any of the other specimens.

In general, the compressional and shear wave velocities exhibited a very small increase 
Table 4

Resonant bar and waveform inversion measurements: Young's modulus and attenuation

\begin{tabular}{lcccc}
\hline Unit & Sample & $\begin{array}{c}\text { Frequency } \\
(\mathrm{HZ})\end{array}$ & $\begin{array}{c}\text { Young's } \\
\text { Modulus } \\
(\mathrm{GPa})\end{array}$ & $\begin{array}{c}\text { Extensional } \\
\text { Attenuation } \\
(1000 / \mathrm{Q})\end{array}$ \\
\hline Resonant bar & & & \\
TCw & GU3-165.35-SNL-B-2 & 13563 & 35.7 & 1.10 \\
PTn & Room dry & & & \\
& G4-135.0-SNL-B & 5279 & 6.8 & 5.40 \\
TSw2 & Boom dry & & & \\
& B-10AE-67-SNL & 20,280 & 40.2 & 2.3 \\
& Room dry & 30,155 & 39.0 & 2.3 \\
& & 40,050 & 38.7 & 2.7 \\
& & 49,667 & 37.7 & 2.7 \\
TSw2 & BB-10-AE-67-SNL & 19,700 & 40.6 & 6.4 \\
& Water-saturated & 29,400 & 39.9 & 6.6 \\
& & 39,000 & 40.0 & 7.3 \\
& & 48,400 & 40.4 & 7.3
\end{tabular}

Waveform Inversion

45,000

36.2

17.9

Room dry

65,000

37.4

21.3

85,000

37.0

19.2

105,000

35.8

18.5

TSw2 BB-10AE-67-SNL

45,000

35.7

31.3

Water-saturated

65,000

36.1

32.3

85,000

36.5

30.3

105,000

35.9

31.3 


\section{GU3-165.35-SNL-B-2}

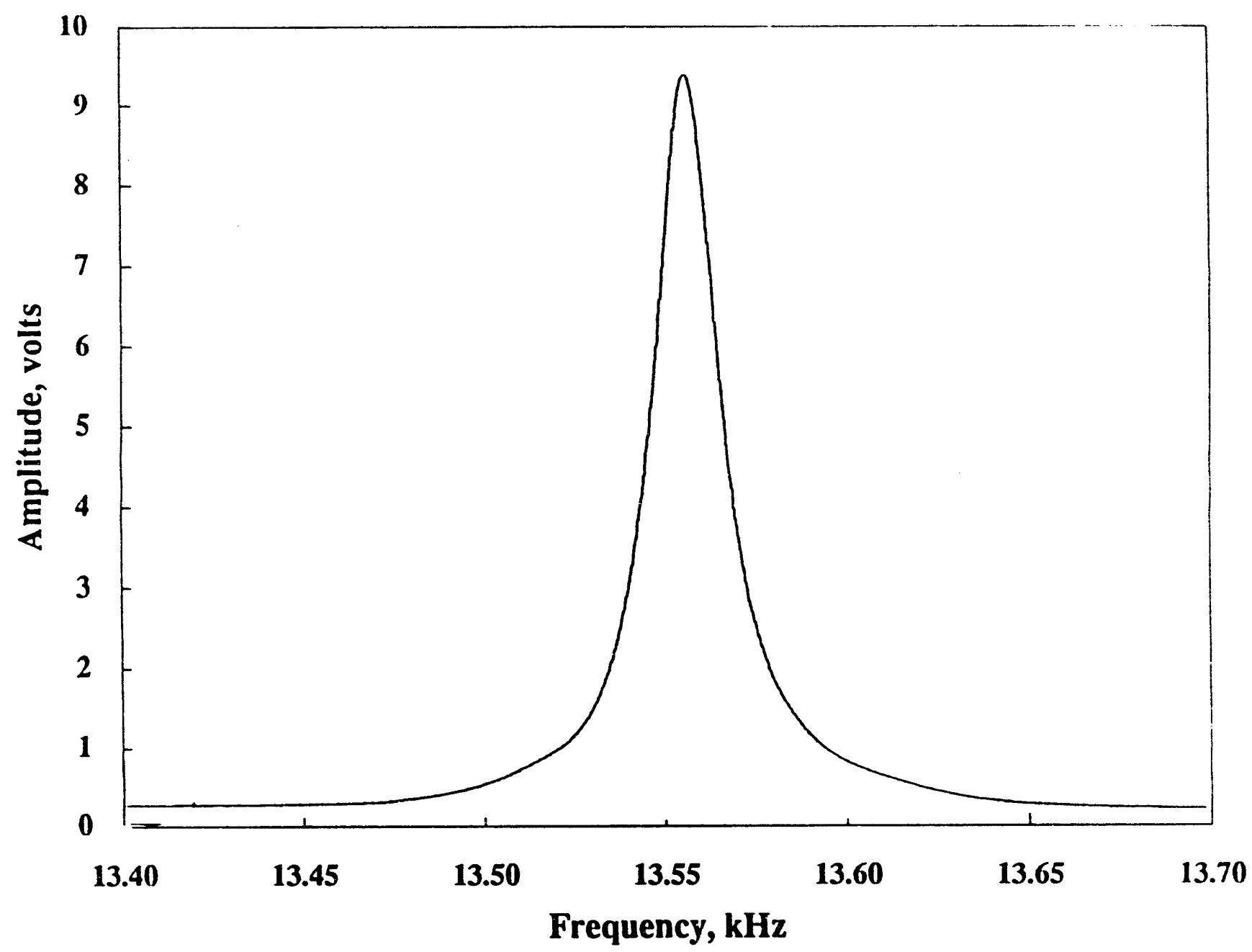

Figure 10: The output voltage from a resonant bar experiment on a specimen of Tiva Canyon tuff is presented. The output amplitude is plotted as a function of frequency; the resonant peak occurs at a frequency near $13.56 \mathrm{kHz}$. 
with increasing confining pressure for both dry and saturated conditions. In most instances, the compressional wave velocity measured on the saturated specimens was greater than that observed on the dry specimen. Shear wave velocity for the saturated specimen was less than that observed for the dry state. The attenuations, $Q_{P}{ }^{-1}$ and $Q_{S}{ }^{-1}$, also showed a very small dependence on confining pressure. In most cases the attenuation decreased with increasing confining pressure up to $15 \mathrm{MPa}$. The data collected on the Tiva Canyon Member (TCw) specimen (GU3-211.3-SNL-A2) are shown graphically in Figures $11 \mathrm{a}$ and $11 \mathrm{~b}$. The compressional and shear wave velocities as well as the corresponding attenuations are plotted as a function of effective confining pressure. This specimen has a low porosity of 1.9\%. In contrast, a nonwelded specimen of PTn (G2-709.7-SNL-B), with a porosity of $48 \%$, showed a pronounced pressure dependence for the compressional wave velocity (most apparent for the dry condition), a small pressure dependence for the shear wave velocity, and attenuations that were independent of confining pressure. These data are shown in Figures 12a and 12b. 
Table 5a

Ultrasonic compressional and shear wave velocities and associated seismic attenuations for dry and water saturated conditions as a function of confining pressure

SAMPLE ID:

ORIENTATION:

PORE FLUID:

TEMPERATURE, ${ }^{\circ} \mathrm{C}:$

SAMPLE LENGTH, $\mathrm{mm}$ :

SAMPLE DIAMETER, mm:

VACUUM DRY WEIGHT, $g$ :

ROOM DRY WEIGHT, $g$ :

SAT WEIGHT, $g$ :

DRY BULK DENSITY, $\mathrm{g} / \mathrm{cm}^{3}$ :

POROSITY, \%:
G1-396.0-SNL-A-1

VERTICAL

DRYNATER

22

25.43

24.84

26.086

26.101

28.064

2.117

16.1
PRESSURE (MPa)

VELOCITY $\left(\mathrm{km} / \mathrm{s}^{-1}\right)$

CONF PORE DIFF P-WAVE S1-WAVE S2-WAVE
VP/VS

RATIO P-WAVE S2-WAVE

\section{ROOM DRY}

$\begin{array}{lll}1.0 & 0.0 & 1.0\end{array}$

4.028

2.473

2.630

1.58

63

102

$\begin{array}{lll}2.5 & 0.0 & 2.5\end{array}$

4.054

2.507

2.646

1.57

61

99

$\begin{array}{lll}5.0 & 0.0 & 5.0\end{array}$

4.106

2.697

1.56

59

93

$\begin{array}{lll}7.5 & 0.0 & 7.5\end{array}$

4.146

2.568

2.720

1.57

56

85

$\begin{array}{lll}10.0 & 0.0 & 10.0\end{array}$

4.160

2.594

2.743

1.56

54

84

$\begin{array}{lll}15.0 & 0.0 & 15.0\end{array}$

4.187

2.610

2.761

1.56

52

83

\section{SATURATED}

\begin{tabular}{lllllllll}
3.5 & 2.5 & 1.0 & 4.443 & 2.346 & 2.301 & 1.91 & 102 & 156 \\
5.0 & 2.5 & 2.5 & 4.459 & 2.381 & 2.331 & 1.89 & 102 & 153 \\
7.5 & 2.5 & 5.0 & 4.483 & 2.421 & 2.379 & 1.87 & 102 & 143 \\
10.0 & 2.5 & 7.5 & 4.498 & 2.454 & 2.406 & 1.85 & 102 & 135 \\
12.5 & 2.5 & 10.0 & 4.506 & 2.473 & 2.438 & 1.84 & 100 & 111 \\
17.5 & 2.5 & 15.0 & 4.522 & 2.498 & 2.452 & 1.83 & 80 & 94 \\
\hline
\end{tabular}

COMMENT: Shear wave polarization randomly oriented. 


\section{Table 5b}

Ultrasonic compressional and shear wave velocities and associated seismic attenuations for dry and water saturated conditions as a function of confining pressure

SAMPLE ID:

ORIENTATION:

PORE FLUID:

TEMPERATURE, ${ }^{\circ} \mathrm{C}$ :

SAMPLE LENGTH, $\mathrm{mm}$ :

SAMPLE DIAMETER, $\mathrm{mm}$ :

VACUUM DRY WEIGHT, g:

ROOM DRY WEIGHT, g:

SAT WEIGHT, $g$ :

DRY BULK DENSITY, $\mathrm{g} / \mathrm{cm}^{3}$ :

POROSITY, \%:
G1-409.9-SNL-A-1

VERTICAL

DRYMATER

22

25.40

24.56

26.860

26.999

28.508

2.232

13.7

\section{PRESSURE (MPa) \\ VELOCITY $\left(\mathrm{km} / \mathrm{s}^{-1}\right)$ \\ VP/VS \\ $1000 / Q$ \\ CONF PORE DIFF \\ P-WAVE S1-WAVE S2-WAVE \\ RATIO \\ P.WAVE S2-WAVE}

ROOM DRY

$\begin{array}{lll}1.0 & 0.0 & 1.0\end{array}$

4.197

2.522

2.455

1.69

159

123

$\begin{array}{ll}2.5 & 0.0\end{array}$

4.225

2.535

2.464

1.69

158

122

$\begin{array}{lll}5.0 & 0.0 & 5.0\end{array}$

4.246

2.548

2.479

1.69

156

123

$\begin{array}{lll}7.5 & 0.0 & 7.5\end{array}$

4.267

2.558

2.488

1.69

152

123

$\begin{array}{lll}10.0 & 0.0 & 10.0\end{array}$

4.275

2.566

1.69

143

120

$\begin{array}{lll}15.0 & 0.0 & 15.0\end{array}$

4.289

2.573

2.503

1.69

135

115

SATURATED

$\begin{array}{lllllllll}3.5 & 2.5 & 1.0 & 4.447 & 2.535 & 2.498 & 1.77 & 154 & 120 \\ 5.0 & 2.5 & 2.5 & 4.462 & 2.540 & 2.498 & 1.77 & 154 & 120 \\ 7.5 & 2.5 & 5.0 & 4.462 & 2.550 & 2.503 & 1.77 & 152 & 119 \\ 10.0 & 2.5 & 7.5 & 4.478 & 2.555 & 2.505 & 1.77 & 147 & 116 \\ 12.5 & 2.5 & 10.0 & 4.486 & 2.560 & 2.510 & 1.77 & 146 & 116 \\ 17.5 & 2.5 & 15.0 & 4.494 & 2.568 & 2.513 & 1.77 & 146 & 114\end{array}$

COMMENT: Shear wave polarization randomly oriented. 
Table 5c

Ultrasonic compressional and shear wave velocities and associated seismic attenuations for dry and water saturated conditions as a function of confining pressure

SAMPLE ID:

ORIENTATION:

PORE FLUID:

TEMPERATURE, ${ }^{\circ} \mathrm{C}$ :

SAMPLE LENGTH, $\mathrm{mm}$ :

SAMPLE DIAMETER, $\mathrm{mm}$ :

VACUUM DRY WEIGHT, $g$ :

ROOM DRY WEIGHT, g:

SAT WEIGHT, $g$ :

DRY BULK DENSITY, $\mathrm{g} / \mathrm{cm}^{3}$ :

POROSITY, \%:

G1-409.9-SNL-A-2
VERTICAL
DRY/WATER
22
25.40
24.51
26.386
27.873
2.202
12.4

G1-409.9-SNL-A-2

VERTICAL

DRY/WATER

25.40

24.51

26.386

27.873

12.4

\begin{tabular}{cccc}
\hline PRESSURE (MPa) & VELOCITY $\left(\mathrm{km} / \mathrm{s}^{-1}\right)$ & VP/VS & $1000 / \mathrm{Q}$ \\
CONF PORE DIFF & P-WAVE S1-WAVE S2-WAVE & RATIO & P-WAVE S2-WAVE
\end{tabular}

\begin{tabular}{|c|c|c|c|c|c|c|c|c|}
\hline \multicolumn{9}{|c|}{ ROOM DRY } \\
\hline 1.0 & 0.0 & 1.0 & 4.163 & 2.517 & 2.479 & 1.67 & 102 & 133 \\
\hline 2.5 & 0.0 & 2.5 & 4.183 & 2.532 & 2.493 & 1.66 & 102 & 133 \\
\hline 5.0 & 0.0 & 5.0 & 4.211 & 2.548 & 2.508 & 1.67 & 102 & 133 \\
\hline 7.5 & 0.0 & 7.5 & 4.225 & 2.555 & 2.518 & 1.67 & 102 & 133 \\
\hline 10.0 & 0.0 & 10.0 & 4.239 & 2.563 & 2.528 & 1.67 & 102 & 133 \\
\hline 15.0 & 0.0 & 15.0 & 4.253 & 2.573 & 2.538 & 1.66 & 101 & 133 \\
\hline \multicolumn{9}{|c|}{ SATURATED } \\
\hline 3.5 & 2.5 & 1.0 & 4.439 & 2.525 & 2.486 & 1.77 & 120 & 111 \\
\hline 5.0 & 2.5 & 2.5 & 4.447 & 2.527 & 2.491 & 1.77 & 120 & 111 \\
\hline 7.5 & 2.5 & 5.0 & 4.447 & 2.543 & 2.503 & 1.76 & 118 & 114 \\
\hline 10.0 & 2.5 & 7.5 & 4.445 & 2.553 & 2.508 & 1.76 & 119 & 114 \\
\hline 12.5 & 2.5 & 10.0 & 4.462 & 2.558 & 2.518 & 1.75 & 119 & 97 \\
\hline 17.5 & 2.5 & 15.0 & 4.462 & 2.566 & 2.523 & 1.77 & 119 & 97 \\
\hline
\end{tabular}

COMMENT: Shear wave polarization randomly oriented. 


\section{Table 5d}

Ultrasonic compressional and shear wave velocities and associated seismic attenuations for dry and water saturated conditions as a function of confining pressure

SAMPLE ID:

ORIENTATION:

PORE FLUID:

TEMPERATURE, ${ }^{\circ} \mathrm{C}:$

G1-721.4-SNL-A-1

VERTICAL

DRY/WATER

SAMPLE LENGTH, $\mathrm{mm}$ :

22

SAMPLE DIAMETER, mm:

25.43

VACUUM DRY WEIGHT, $g$ :

24.82

ROOM DRY WEIGHT, g:

27.752

27.767

SAT WEIGHT, g:

28.632

DRY BULK DENSITY, $\mathrm{g}^{\prime} \mathrm{cm}^{3}$ :

2.257

POROSITY, \%:

7.2

\begin{tabular}{ccccc}
\hline \multicolumn{2}{c}{ PRESSURE (MPa) } & VELOCITY $\left(\mathrm{km} / \mathrm{s}^{-1}\right)$ & VP/VS & $1000 / \mathrm{Q}$ \\
CONF PORE DIFF & P-WAVE S1-WAVE S2-WAVE & RATIO & P-WAVE S2-WAVE
\end{tabular}

ROOM DRY

$\begin{array}{lll}1.0 & 0.0 & 1.0\end{array}$

$2.5 \quad 0.0 \quad 2.5$

$\begin{array}{ll}.0 & 4.337\end{array}$

2.740

2.735

1.58

30

62

$5.0 \quad 0.0$

4.345

2.749

2.746

1.58

30

62

$\begin{array}{lll}7.5 & 0.0 & 7.5\end{array}$

4.360

2.758

2.752

1.58

29

61

$\begin{array}{lll}10.0 & 0.0 & 10.0\end{array}$

4.360

2.764

2.758

1.58

56

$\begin{array}{lll}15.0 & 0.0 & 15.0\end{array}$

4.367

2.767

2.758

1.58

52

4.367

2.773

2.764

1.58

52

SATURATED

\begin{tabular}{lllllllll}
3.5 & 2.5 & 1.0 & 4.397 & 2.685 & 2.735 & 1.62 & 53 & 89 \\
5.0 & 2.5 & 2.5 & 4.405 & 2.708 & 2.697 & 1.63 & 49 & 89 \\
7.5 & 2.5 & 5.0 & 4.413 & 2.693 & 2.697 & 1.64 & 48 & 83 \\
10.0 & 2.5 & 7.5 & 4.428 & 2.699 & 2.703 & 1.64 & 44 & 71 \\
12.5 & 2.5 & 10.0 & 4.428 & 2.702 & 2.705 & 1.64 & 44 & 65 \\
17.5 & 2.5 & 15.0 & 4.436 & 2.708 & 2.708 & 1.64 & 45 & 61 \\
\hline
\end{tabular}

COMMENT: Shear wave polarization randomly oriented. 
Table Se

Ultrasonic compressional and shear wave velocities and associated seismic attenuations for dry and water saturated conditions as a function of confining pressure

SAMPLE ID:

ORIENTATION:

PORE FLUID:

TEMPERATURE, ${ }^{\circ} \mathrm{C}$

G1-906.0-SNL-B-1

HORIZONTAL

DRY/WATER

SAMPLE LENGTH, $\mathrm{mm}$ :

22

SAMPLE DIAMETER, $\mathrm{mm}$ :

25.40

24.87

VACUUM DRY WEIGHT, g:

28.201

ROOM DRY WEIGHT, g:

28.202

SAT WEIGHT, g:

29.341

DRY BULK DENSITY, $\mathrm{g} / \mathrm{cm}^{3}$ :

2.286

POROSITY, \%:

9.2

\begin{tabular}{cccc}
\hline PRESSURE (MPa) & VELOCITY $\left(\mathrm{km}^{-1} \mathrm{~s}^{-1}\right)$ & VP/VS & $1000 / \mathrm{Q}$ \\
CONF PORE DIFF & P-WAVE S1-WAVE S2-WAVE & RATIO & P-WAVE S2-WAVE
\end{tabular}

ROOM DRY

$\begin{array}{lllllllll}1.0 & 0.0 & 1.0 & 4.416 & 2.691 & 2.720 & 1.63 & 105 & 100 \\ 2.5 & 0.0 & 2.5 & 4.431 & 2.711 & 2.732 & 1.63 & 97 & 86 \\ 5.0 & 0.0 & 5.0 & 4.462 & 2.737 & 2.750 & 1.63 & 83 & 79 \\ 7.5 & 0.0 & 7.5 & 4.486 & 2.752 & 2.758 & 1.63 & 72 & 74 \\ 10.0 & 0.0 & 10.0 & 4.502 & 2.758 & 2.767 & 1.63 & 67 & 71 \\ 15.0 & 0.0 & 15.0 & 4.510 & 2.770 & 2.774 & 1.63 & 58 & 70\end{array}$

SATURATED

\begin{tabular}{lllllllll}
3.5 & 2.5 & 1.0 & 4.608 & 2.758 & 2.700 & 1.69 & 74 & 100 \\
5.0 & 2.5 & 2.5 & 4.608 & 2.764 & 2.714 & 1.68 & 70 & 98 \\
7.5 & 2.5 & 5.0 & 4.625 & 2.761 & 2.711 & 1.69 & 68 & 96 \\
10.0 & 2.5 & 7.5 & 4.642 & 2.740 & 2.717 & 1.70 & 63 & 94 \\
12.5 & 2.5 & 10.0 & 4.659 & 2.746 & 2.726 & 1.70 & 61 & 83 \\
17.5 & 2.5 & 15.0 & 4.667 & 2.761 & 2.738 & 1.70 & 60 & 77 \\
\hline
\end{tabular}

COMMENT: Shear wave polarization randomly oriented. 
Table $5 f$

Ultrasonic compressional and shear wave velocities and associated seismic attenuations for dry and water saturated conditions as a function of confining pressure

SAMPLE ID:

ORIENTATION:

PORE FLUID:

TEMPERATURE, ${ }^{\circ} \mathrm{C}$ :

SAMPLE LENGTH, $\mathrm{mm}$ :

SAMPLE DIAMETER, $\mathrm{mm}$ :

VACUUM DRY WEIGHT, $g$ :

ROOM DRY WEIGHT, g:

SAT WEIGHT, $g$ :

DRY BULK DENSITY, $\mathrm{g} / \mathrm{cm}^{3}$ :

POROSITY, \%:

G1-1157.5-SNL-A-1
VERTICAL
DRYWATER
22
25.65
24.59
28.043
28.136
29.055
2.302
8.3

\begin{tabular}{cccc}
\hline PRESSURE (MPa) & VELOCITY $\left(\mathrm{km} / \mathrm{s}^{-1}\right)$ & VP/VS & $1000 / \mathrm{Q}$ \\
CONF PORE DIFF & P-WAVE S1-WAVE S2-WAVE & RATIO & P-WAVE S2-WAVE
\end{tabular}

\section{ROOM DRY}

$\begin{array}{lllllllll}1.0 & 0.0 & 1.0 & 3.970 & 2.658 & 2.587 & 1.51 & 104 & 45 \\ 2.5 & 0.0 & 2.5 & 4.013 & 2.658 & 2.600 & 1.53 & 118 & 45 \\ 5.0 & 0.0 & 5.0 & 4.026 & 2.658 & 2.621 & 1.53 & 119 & 43 \\ 7.5 & 0.0 & 7.5 & 4.020 & 2.661 & 2.626 & 1.52 & 118 & 43 \\ 10.0 & 0.0 & 10.0 & 4.032 & 2.672 & 2.648 & 1.52 & 111 & 42 \\ 15.0 & 0.0 & 15.0 & 4.090 & 2.686 & 2.665 & 1.53 & 110 & 41\end{array}$

\section{SATURATED}

$\begin{array}{lllllllll}3.5 & 2.5 & 1.0 & 4.289 & 2.594 & 2.551 & 1.67 & 69 & 49 \\ 5.0 & 2.5 & 2.5 & 4.296 & 2.602 & 2.561 & 1.66 & 68 & 48 \\ 7.5 & 2.5 & 5.0 & 4.296 & 2.602 & 2.566 & 1.66 & 66 & 48 \\ 10.0 & 2.5 & 7.5 & 4.310 & 2.604 & 2.571 & 1.67 & 65 & 47 \\ 12.5 & 2.5 & 10.0 & 4.317 & 2.607 & 2.579 & 1.67 & 63 & 46 \\ 17.5 & 2.5 & 15.0 & 4.339 & 2.618 & 2.587 & 1.67 & 62 & 46\end{array}$

COMMENT: Shear wave polarization randomly oriented. 
Table 5g

Ultrasonic compressional and shear wave velocities and associated seismic attenuations for dry and water saturated conditions as a function of confining pressure

SAMPLE ID:

ORIENTA'TION:

PORE FLUID:

TEMPERATURE, ${ }^{\circ} \mathrm{C}$ :

SAMPLE LENGTH, mm:

SAMPLE DIAMETER, $\mathrm{mm}$ :

VACUUM DRY WEIGHT, g:

ROOM DRY WEIGHT, $g$ :

SAT WEIGHT, $g$ :

DRY BULK DENSITY, $\mathrm{g} / \mathrm{cm}^{3}$ : POROSITY, \%:
G1-1406.3-SNL-A-1

VERTICAL

DRY/WATER

22

25.30

22.22

14.544

14.804

18.01

1.482

35.3
PRESSURE (MPa) CONF PORE DIFF

\section{$\operatorname{VELOCITY~}\left(\mathrm{km} / \mathrm{s}^{-1}\right)$}

P-WAVE S1-WAVE S2-WAVE
VP/VS

1000/Q

RATIO P-WAVE S2-WAVE

\section{ROOM DRY}

$\begin{array}{lll}1.0 & 0.0 & 1.0\end{array}$

$\begin{array}{lll}2.5 & 0.0 & 2.5\end{array}$

$\begin{array}{lll}5.0 & 0.0 & 5.0\end{array}$

$\begin{array}{lll}7.5 & 0.0 & 7.5\end{array}$

$\begin{array}{lll}10.0 & 0.0 & 10.0\end{array}$

2.563

1.511

1.507

1.70

310

156

$\begin{array}{lll}15.0 & 0.0 & 15.0\end{array}$

2.573

1.531

1.529

1.68

310

$2.605 \quad 1.558 \quad 1.561$

1.67

310

139

SATURATED

$\begin{array}{lllllllll}3.5 & 2.5 & 1.0 & 2.688 & 1.009 & 1.010 & 2.66 & 272 & 108 \\ 5.0 & 2.5 & 2.5 & 2.699 & 1.014 & 1.015 & 2.66 & 270 & 83 \\ 7.5 & 2.5 & 5.0 & 2.723 & 1.023 & 1.026 & 2.66 & 262 & 68 \\ 10.0 & 2.5 & 7.5 & 2.770 & 1.033 & 1.036 & 2.68 & 256 & 63 \\ 12.5 & 2.5 & 10.0 & 2.776 & 1.044 & 1.047 & 2.66 & 241 & 57 \\ 17.5 & 2.5 & 15.0 & 2.839 & 1.065 & 1.065 & 2.67 & 241 & 56\end{array}$

COMMENT: Poor signal at low confining pressures. Unable to define first break of signal for dry sample measurements. 
Table 5h

Ultrasonic compressional and shear wave velocities and associated seismic attenuations for dry and water saturated conditions as a function of confining pressure

SAMPLE ID:

ORIENTATION:

PORE FLUID:

TEMPERATURE, ${ }^{\circ} \mathrm{C}$ :

SAMPLE LENGTH, mm:

SAMPLE DIAMETER, $\mathrm{mm}$ :

VACUUM DRY WEIGHT, g:

ROOM DRY WEIGHT, g:

SAT WEIGHT, $g$ :

DRY BULK DENSITY, $\mathrm{g} / \mathrm{cm}^{3}$ :

POROSITY, \%:
G2-709.7-SNL-B-1

HORIZONTAL

DRY/WATER

$$
22
$$

25.60

23.16

13.646

14.556

18.834

1.265

48.1

\begin{tabular}{cccc}
\hline & & & \\
PRESSURE (MPa) & VELOCITY $\left(\mathrm{km}^{-1} \mathrm{~s}^{-1}\right)$ & VP/VS & $1000 / \mathrm{Q}$ \\
CONF PORE DIFF & P-WAVE S1-WAVE S2-WAVE & RATIO & P-WAVE S2-WAVE
\end{tabular}

\section{ROOM DRY}

$\begin{array}{lllllllll}1.0 & 0.0 & 1.0 & 1.619 & 1.006 & 1.006 & 1.61 & 315 & 59 \\ 2.5 & 0.0 & 2.5 & 1.640 & 1.010 & 1.011 & 1.62 & 315 & 56 \\ 5.0 & 0.0 & 5.0 & 2.086 & 1.018 & 1.023 & 2.04 & 315 & 56 \\ 7.5 & 0.0 & 7.5 & 2.263 & 1.022 & 1.025 & 2.21 & 315 & 54 \\ 10.0 & 0.0 & 10.0 & 2.372 & 1.034 & 1.032 & 2.30 & 315 & 53 \\ 15.0 & 0.0 & 15.0 & 2.431 & 1.047 & 1.050 & 2.32 & 315 & 53\end{array}$

\section{SATURATED}

\begin{tabular}{lllllllll}
3.5 & 2.5 & 1.0 & 2.351 & 1.021 & 1.029 & 2.29 & 313 & 59 \\
5.0 & 2.5 & 2.5 & 2.404 & 1.024 & 1.034 & 2.34 & 310 & 59 \\
7.5 & 2.5 & 5.0 & 2.483 & 1.032 & 1.043 & 2.39 & 286 & 60 \\
10.0 & 2.5 & 7.5 & 2.542 & 1.042 & 1.053 & 2.43 & 251 & 60 \\
12.5 & 2.5 & 10.0 & 2.578 & 1.053 & 1.075 & 2.42 & 238 & 26 \\
17.5 & 2.5 & 15.0 & 2.675 & 1.091 & 1.103 & 2.44 & 228 & 52 \\
\hline
\end{tabular}

COMMENT: Shear wave polarization randomly oriented.

Sample became disintegrated upon saturation. 
Table 5i

Ultrasonic compressional and shear wave velocities and associated seismic attenuations for dry and water saturated conditions as a function of confining pressure

SAMPLE ID:

ORIENTATION:

PORE FLUID:

TEMPERATURE, ${ }^{\circ} \mathrm{C}$ :

SAMPLE LENGTH, $\mathrm{mm}$ :

SAMPLE DIAMETER, $\mathrm{mm}$ :

VACUUM DRY WEIGHT, g:

ROOM DRY WEIGHT, g:

SAT WEIGHT, g:

DRY BULK DENSITY, $g / \mathrm{cm}^{3}$ :

POROSITY, \%:

GU3-165.35-SNL-A-1
VERTICAL
DRYNATER
22
25.43
24.59
27.389
27.396
28.209
2.269
6.8

\begin{tabular}{cccc}
\hline PRESSURE (MPa) & VELOCITY $\left(\mathrm{km} / \mathrm{s}^{-1}\right)$ & VP/VS & $1000 / \mathrm{Q}$ \\
CONF PORE DIFF & P-WAVE S1-WAVE S2-WAVE & RATIO & P-WAVE S2-WAVE
\end{tabular}

ROOM DRY

4.630

2.822

2.832

1.64

97

97

$\begin{array}{ll}2.5 & 0.0\end{array}$

2.5

4.646

2.834

2.848

1.64

97

94

$\begin{array}{lll}5.0 & 0.0 & 5.0\end{array}$

4.655

2.841

2.857

1.63

89

$\begin{array}{lll}7.5 & 0.0 & 7.5\end{array}$

4.663

2.844

2.861

1.63

85

$\begin{array}{lll}10.0 & 0.0 & 10.0\end{array}$

4.663

2.847

2.864

1.63

81

$\begin{array}{lll}15.0 & 0.0 & 15.0\end{array}$

4.672

2.854

2.874

1.63

78

SATURATED

$\begin{array}{lll}3.5 & 2.5 & 1.0\end{array}$

$\begin{array}{lll}5.0 & 2.5 & 2.5\end{array}$

$\begin{array}{lll}7.5 & 2.5 & 5.0\end{array}$

$\begin{array}{lll}10.0 & 2.5 & 7.5\end{array}$

$\begin{array}{lll}12.5 & 2.5 & 10.0\end{array}$

$\begin{array}{lll}17.5 & 2.5 & 15.0\end{array}$
4.663

4.681

2.806

2.810

2.809

2.816

4.689

2.816

2.832

2.822

2.835

2.825

2.841

2.831

2.848
1.66

1.66

1.66

1.66

1.66

1.66
65

64

61

59

56

52
109

106

91

83

77

71

COMMENT: Shear wave polarization randomly oriented. 
Table 5j

Ultrasonic compressional and shear wave velocities and associated seismic attenuations for dry and water saturated conditions as a function of confining pressure

SAMPLE ID:

ORIENTATION:

PORE FLUID:

TEMPERATURE, ${ }^{\circ} \mathrm{C}$ :

SAMPLE LENGTH, $\mathrm{mm}$ :

SAMPLE DIAMETER, $\mathrm{mm}$ :

VACUUM DRY WEIGHT, $g$ :

ROOM DRY WEIGHT, $g$ :

SAT WEIGHT, g:

DRY BULK DENSITY, $g / \mathrm{cm}^{3}$ :

POROSITY, \%:
GU3-211.3-SNL-A-2

VERTICAL

DRY/WATER

22

25.43

24.82

28.6

28.62

28.837

2.326

1.9

\begin{tabular}{cccc}
\hline PRESSURE (MPa) & VELOCITY $\left(\mathrm{km} / \mathrm{s}^{-1}\right)$ & VP/VS & $1000 / \mathrm{Q}$ \\
CONF PORE DIFF & P-WAVE S1-WAVE S2-WAVE & RATIO & P-WAVE S2-WAVE
\end{tabular}

\section{ROOM DRY}

$\begin{array}{lll}1.0 & 0.0 & 1.0\end{array}$

4.724

2.929

2.937

1.61

71

82

$\begin{array}{lll}2.5 & 0.0 & 2.5\end{array}$

4.733

2.936

2.940

1.61

71

82

$\begin{array}{lll}5.0 & 0.0 & 5.0\end{array}$

4.733

2.943

2.947

1.61

71

77

$\begin{array}{lll}7.5 & 0.0 & 7.5\end{array}$

4.742

2.946

2.950

1.61

66

75

$\begin{array}{lll}10.0 & 0.0 & 10.0\end{array}$

4.751

2.950

2.954

1.61

66

71

$\begin{array}{lll}15.0 & 0.0 & 15.0\end{array}$

$4.760 \quad 2.953$

2.957

1.61

68

69

SATURATED

\begin{tabular}{lllllllll}
3.5 & 2.5 & 1.0 & 4.689 & 2.899 & 2.893 & 1.62 & 87 & 65 \\
5.0 & 2.5 & 2.5 & 4.715 & 2.906 & 2.896 & 1.63 & 87 & 65 \\
7.5 & 2.5 & 5.0 & 4.724 & 2.916 & 2.906 & 1.62 & 85 & 64 \\
10.0 & 2.5 & 7.5 & 4.724 & 2.922 & 2.910 & 1.62 & 83 & 62 \\
12.5 & 2.5 & 10.0 & 4.733 & 2.929 & 2.916 & 1.62 & 83 & 60 \\
17.5 & 2.5 & 15.0 & 4.724 & 2.936 & 2.920 & 1.62 & 81 & 56 \\
\hline
\end{tabular}

COMMENT: Shear wave polarization randomly oriented. 
Table 5k

Ultrasonic compressional and shear wave velocities and associated seismic attenuations for dry and water saturated conditions as a function of confining pressure

SAMPLE ID:

ORIENTATION:

PORE FLUID:

TEMPERATURE, ${ }^{\circ} \mathrm{C}$ :

SAMPLE LENGTH, $\mathrm{mm}$ :

SAMPLE DIAMETER, mm:

VACUUM DRY WEIGHT, g:

ROOM DRY WEIGHT, g:

SAT WEIGHT, g:

DRY BULK DENSITY, $\mathrm{g} / \mathrm{cm}^{3}$ :

POROSITY, \%:
G4-135-0-SNL-A-1

VERTICAL

DRY/WATER

22

25.73

22.48

14.193

14.256

17.817

1.390

35.5
PRESSURE (MPa) CONF PORE DIFF
VELOCITY $\left(\mathrm{km} / \mathrm{s}^{-1}\right)$ P-WAVE S1-WAVE S2-WAVE
VP/VS

RATIO P-WAVE S2-WAVE

\section{ROOM DRY}

$\begin{array}{lll}1.0 & 0.0 & 1.0\end{array}$

$\begin{array}{lll}2.5 & 0.0 & 2.5\end{array}$

$\begin{array}{lll}5.0 & 0.0 & 5.0\end{array}$

2.175

1.243

1.295

1.71

145

94

$\begin{array}{lll}7.5 & 0.0 & 7.5\end{array}$

2.332

1.489

1.412

1.61

1.584

1.424

1.65

145

94

$\begin{array}{lll}10.0 & 0.0 & 10.0\end{array}$

2.596

1.624

1.471

1.68

$\begin{array}{lll}15.0 & 0.0 & 15.0\end{array}$

2.716

1.680

1.534

1.69

145

145

94

94

145

94

94

SATURATED

$\begin{array}{lllllllll}3.5 & 2.5 & 1.0 & 2.694 & 1.023 & 1.028 & 2.63 & 188 & 71 \\ 5.0 & 2.5 & 2.5 & 2.745 & 1.030 & 1.034 & 2.66 & 182 & 68 \\ 7.5 & 2.5 & 5.0 & 2.818 & 1.043 & 1.043 & 2.70 & 157 & 63 \\ 10.0 & 2.5 & 7.5 & 2.868 & 1.061 & 1.053 & 2.71 & 157 & 52 \\ 12.5 & 2.5 & 10.0 & 2.894 & 1.080 & 1.068 & 2.69 & 157 & 48 \\ 17.5 & 2.5 & 15.0 & 2.960 & 1.106 & 1.098 & 2.69 & 134 & 44\end{array}$

COMMENT: Shear wave polarization randomly oriented.

Poor signal at lowest confining pressure level. 
Table 51

Ultrasonic compressional and shear wave velocities and associated seismic attenuations for dry and water saturated conditions as a function of confining pressure

SAMPLE ID:

ORIENTATION:

PORE FLUID:

TEMPERATURE, ${ }^{\circ} \mathrm{C}$ :

SAMPLE LENGTH, $\mathrm{mm}$ :

SAMPLE DIAMETER, $\mathrm{mm}$ :

VACUUM DRY WEIGHT, g:

ROOM DRY WEIGHT, g:

SAT WEIGHT, g:

DRY BULK DENSITY, $\mathrm{g} / \mathrm{cm}^{3}$ :

POROSITY, \%:
G4-1617.75-SNL-A-1

VERTICAL

DRY/WATER

22

25.68

23.95

18.666

18.979

22.031

1.613

29.1

\section{PRESSURE (MPa) \\ $\operatorname{VELOCITY~}\left(\mathrm{km} / \mathrm{s}^{-1}\right)$ \\ P-WAVE S1-WAVE S2-WAVE \\ VP/VS \\ RATIO \\ $1000 / Q$ \\ P-WAVE S2-WAVE}

\section{ROOM DRY}

$\begin{array}{lllllllll}1.0 & 0.0 & 1.0 & 2.927 & 2.019 & 1.959 & 1.47 & 155 & 149 \\ 2.5 & 0.0 & 2.5 & 3.139 & 2.061 & 1.974 & 1.56 & 155 & 149 \\ 5.0 & 0.0 & 5.0 & 3.142 & 2.000 & 2.008 & 1.57 & 155 & 149 \\ 7.5 & 0.0 & 7.5 & 3.142 & 2.016 & 2.027 & 1.55 & 154 & 149 \\ 10.0 & 0.0 & 10.0 & 3.146 & 2.025 & 2.043 & 1.55 & 154 & 149 \\ 15.0 & 0.0 & 15.0 & 3.154 & 2.045 & 2.046 & 1.54 & 155 & 149\end{array}$

SATURATED

$\begin{array}{lllllllll}3.5 & 2.5 & 1.0 & 3.382 & 1.759 & 1.760 & 1.92 & 180 & 44 \\ 5.0 & 2.5 & 2.5 & 3.391 & 1.764 & 1.765 & 1.92 & 180 & 44 \\ 7.5 & 2.5 & 5.0 & 3.409 & 1.781 & 1.782 & 1.91 & 180 & 44 \\ 10.0 & 2.5 & 7.5 & 3.409 & 1.793 & 1.795 & 1.90 & 137 & 40 \\ 12.5 & 2.5 & 10.0 & 3.428 & 1.814 & 1.812 & 1.89 & 137 & 40 \\ 17.5 & 2.5 & 15.0 & 3.437 & 1.824 & 1.823 & 1.88 & 125 & 40\end{array}$

COMMENT: Shear wave polarization randomly oriented. 
Tiva Canyon Welded Tuff - Ultrasonic Velocities

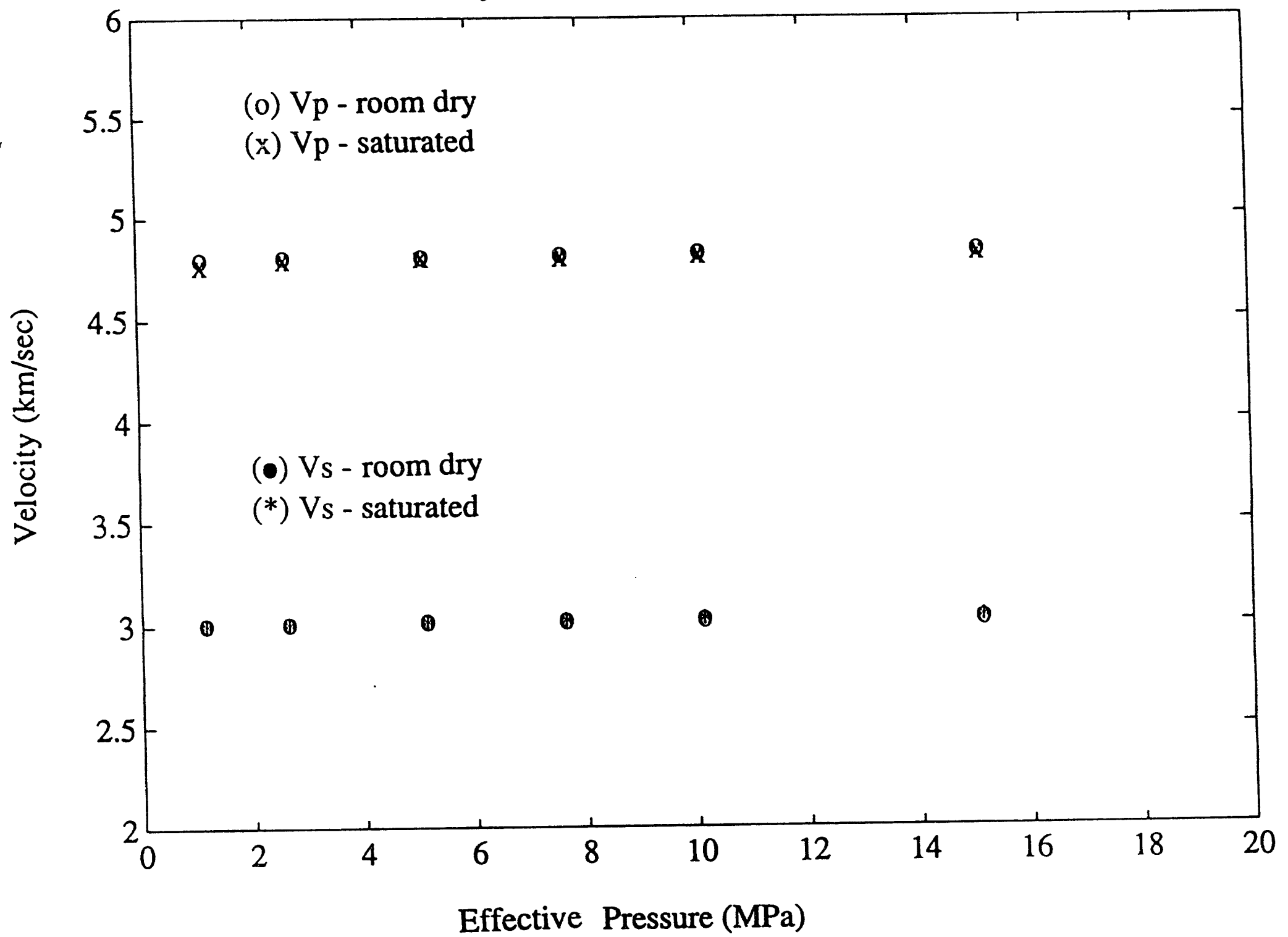

Figure 11a: The compressional and shear wave velocities for dry and saturated conditions are shown as a function of pressure for a Tiva Canyon tuff (GU3-211.3-SNL-A2). The solid symbols indicate data collected in a saturated condition; the open symbols indicate data collected in a dry condition. Circles are compressional velocity; the squares are shear wave data. 
Tiva Canyon Welded Tuff - Attenuation

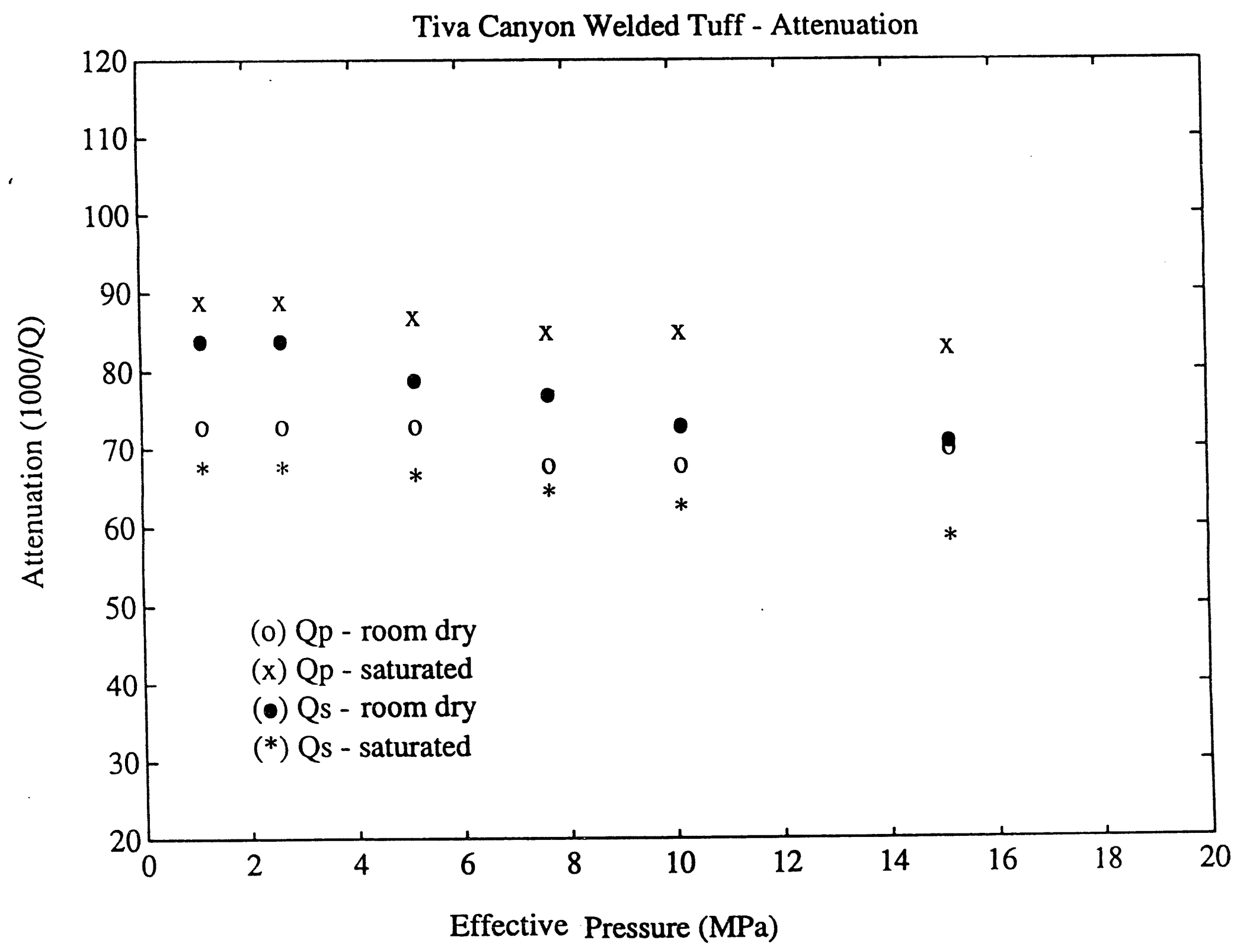

Figure 11b: The seismic wave attenuation is shown as a function of confining pressure for a specimen of Tiva Canyon tuff (GU3-211.3-SNL-A2). The solid symbols are attenuation measured in the saturated state; the open symbols indicate data collected on a dry specimen. Circles indicate compressional attenuation; squares indicate shear attenuation. 


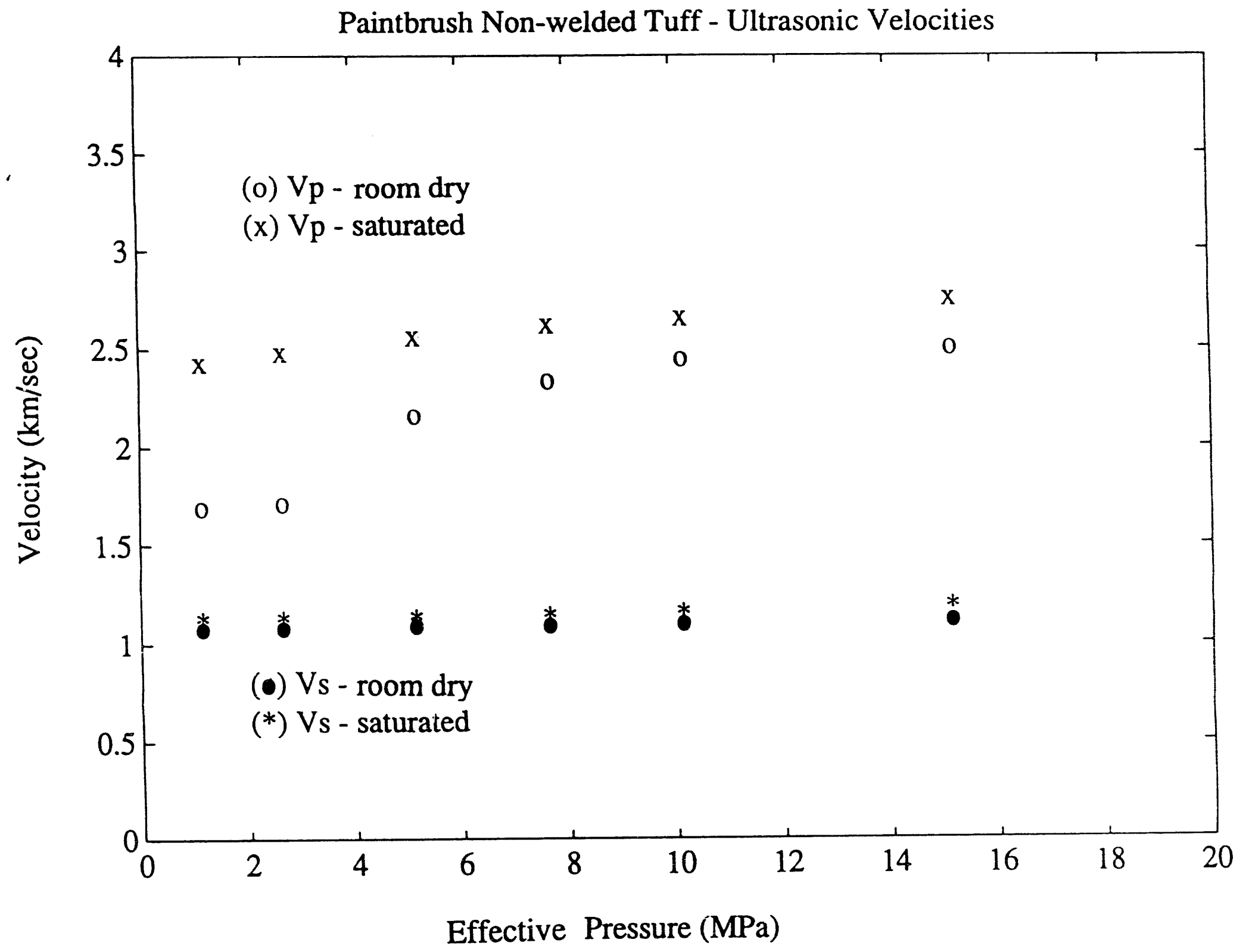

Figure 12a: Compressional and shear wave velocities for a specimen of the Paintbrush tuff (G2-7097-SNL-B) are shown as a function of confining pressure. The solid symbols indicate data collected under saturated conditions; the open circles indicate data collested in a drv state. Circles are compressional velocity; the squares indicate shear velocity. 
Paintbrush Non-welded Tuff - Attenuation

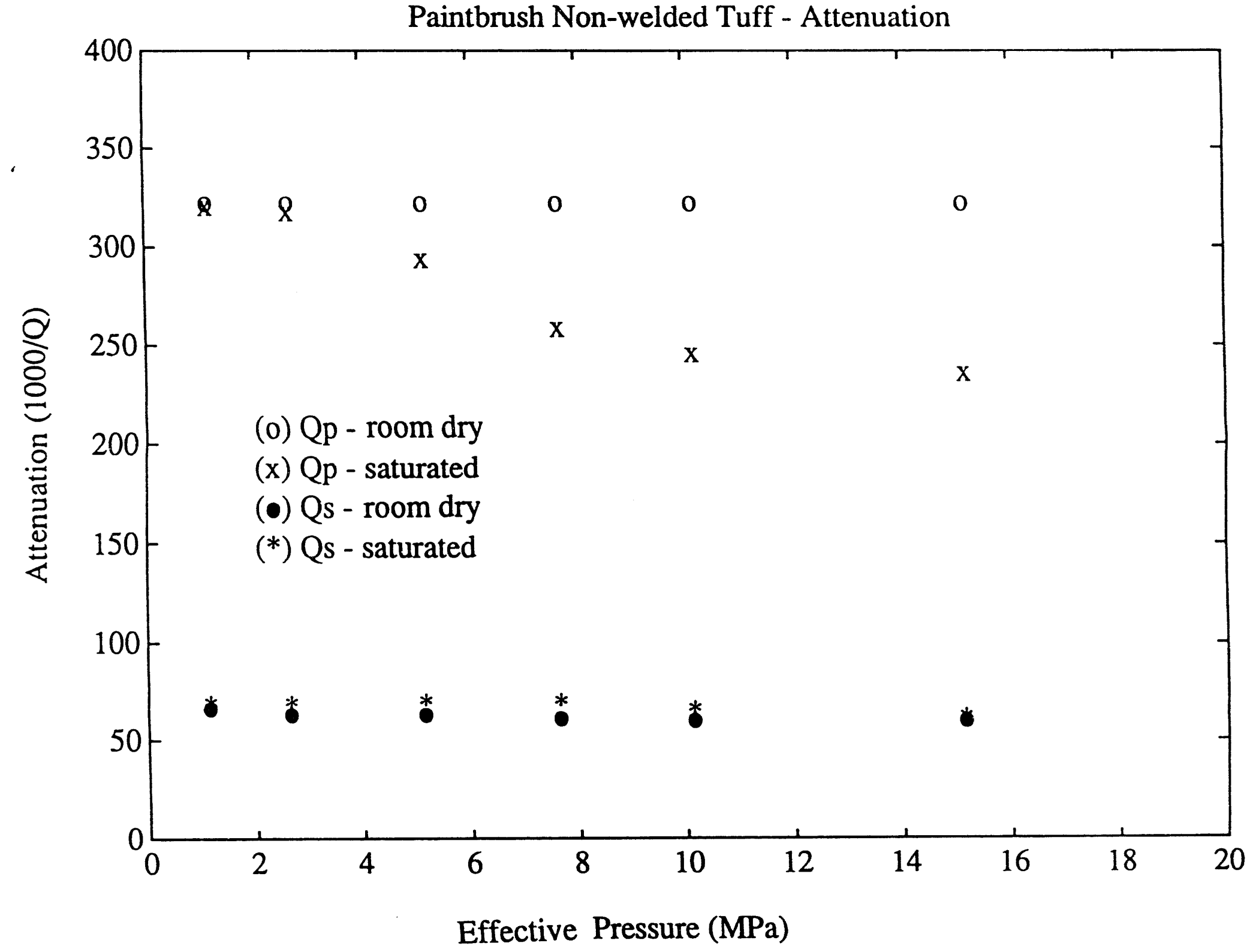

Figure 12b: Seismic wave attenuation is plotted as a function of confining pressure for a specimen of the Paintbrush tuff (G2-709.7-SNL-B). The solid symbol indicates data collected under saturated conditions; the open symbol indicates data collected for a dry state. Circles indicate compression attenuation; squares represent shear attenuation. 


\subsection{DISCUSSION}

Four techniques were used to measure Young's modulus and $\mathrm{Q}^{-1}$ as a function of frequency, strain amplitude, and saturation for specimens of the tuff from near and on Yucca Mountain. Dispersion data for Young's modulus and extensional attenuation were obtained for one specimen of Topopah Spring Member (TSw2) tuff. The different techniques produced comparable results. Differences observed in the attenuation values obtained using the waveform inversion and resonant bar techniques are attributable to sample inhomogeneity. Tuff is highly heterogeneous, yielding a large scatter in rock properties (e.g. Price et al., 1987). The inhomogeneities in the tuff (e.g., pores, pumice fragments, vapor phase altered zones, lithics, and lithophysae) range in size from microscopic to several centimeters. The relatively small subsamples taken for these measurements probably contain different quantities of inhomogeneities, producing scatter in the modulus and attenuation data for the two techniques. Comparisons of these techniques on relatively homogeneous granite specimens with uniform grain sizes on the order of $0.5 \mathrm{~mm}$, yield nearly identical moduli and attenuations for dry specimens (Haupt et al., 1992).

The partial data sets obtained for the other tuff specimens were not sufficient to define the modulus dispersion. However, these results are useful for examining the relative differences in modulus and attenuation caused by porosity, fabric, sample heterogeneity, and compositional variations.

\subsection{Young's Modulus: The Effects of Frequency and Water Saturation}

Young's modulus shows a slight frequency dependence in room dry tuff. The moduli for the saturated tuff typically are less than the corresponding room dry measurements, except at ultrasonic frequencies, at which the data are inconsistent. The reduction in modulus for the saturated state can be attributed to the reduction of surface energy along the grain boundaries, microcracks, and pores within the rock (Murphy, 1982; Bulau et al., 1984; Murphy et al., 1984). Modulus reduction is more pronounced in granite and other low porosity crystalline rocks than for the tuff. This is due, at least in part, to the pore geometry. Granites are characterized by low aspect ratio cracks, whereas the pore structure of the welded tuff consists predominantly of ellipsoidal pores and lithophysal zones (Price et al., 1987).

The frequency dependence of the modulus can be attributed to fluid flow within the 
sample. When the cyclic loading rate exceeds the time constant for fluid diffusion within the pore space, the specimen begins to stiffen because of the compression of the pore water. In turn, the effective modulus increases. The point at which the relative stiffening occurs is directly related to the sample diameter, the pore geometry, and the boundary conditions for fluid flow within the specimen (Spencer, 1981; Dunn, 1987).

\subsection{Attenuation: The Effects of Erequency and Water Saturation}

The $\mathrm{Q}_{\mathrm{E}}^{-1}$ in the room dry condition is relatively low and is, at least to the first order, independent of frequency. These observations are consistent with previous data (Spencer, 1981; Winkler et al., 1979; Murphy et al., 1984). The resonant bar and waveform inversion data exhibit a significant difference in $\mathrm{Q}_{\mathrm{E}}^{-1}$ that is attributable to sample heterogeneity. Lucet et al. (1991) have shown that sample heterogeneity significantly affects the modulus and attenuation measurements.

Water-saturated welded tuffs show larger $\mathrm{Q}_{\mathrm{E}}^{-1}$ than the room dry specimens at nearly all frequencies. The attenuation is frequency dependent. At frequencies less than $1 \mathrm{~Hz}$, the dry and saturated attenuation for tuff are nearly the same. However, at higher frequencies (between 1 and $10^{2} \mathrm{~Hz}$ ), $\mathrm{Q}_{\mathrm{E}}^{-1}$ increases nearly fivefold. Between $10^{4}$ and $2 \times 10^{5} \mathrm{~Hz}$, resonant bar and waveform inversion techniques display a consistently greater attenuation for the saturated condition than for the dry condition. Comparisons between the measurements at these frequencies do not yield consistent results; the differences are most likely caused by sample heterogeneity.

The increase in $\mathrm{Q}_{\mathrm{E}}^{-1}$ with frequency for water-saturated specimens can be attributed to a number of mechanisms. The fluid flow in the pores is strongly frequency-dependent and can give rise to attenuation. Models have been proposed by Gardner (1962), Walsh (1969), Mavko and Nur (1979), O'Connell and Budiansky (1977), and White (1986) to explain the experimental data; attenuation is attributed to the relative motion between the fluid and pore. As the loading frequency increases, the rate of fluid flow increases and viscous losses control the attenuation. Once the deformation rate is significantly greater than the pore fluid response, stiffening occurs and attenuation decreases. The data for tuff does not exhibit the stiffening or the corresponding decrease in attenuation. Fluid flow is governed by the boundary conditions imposed by the experimental setup, the sample geometry, and the pore geometry. For the small diameter tuff specimens with a relatively high porosity and rounded pores, flow in and out of the pores and stiffening of the fluid was minimal. 
(Note: All the specimens were tested under drained conditions.)

\subsection{Effect of Strain Amolitude on Modulus and Attenuation}

The effect of strain amplitude on Young's modulus and seismic wave attenuation has been considered by a number of investigators (Walsh, 1969; Mavko, 1979; Winkler et al., 1979). For rocks with low aspect ratio cracks, the modulus has been shown to decrease with increasing strain amplitude. Several models have been forwarded to explain the decrease. Walsh (1969), Mavko (1979), and Winkler et al. (1979) have proposed frictional mechanisms in which sliding on microcracks dissipates energy, observed as attenuation. Alternative mechanisms based on changes in surface energy and movement of fluid films in partially saturated rocks have been proposed by Spencer (1981), Mavko and Nur (1979), Bulau et al. (1984) and Murphy et al. (1984). Young's modulus and attenuation for the tuff showed no strain amplitude dependence for either the dry or saturated conditions. By way of comparison, the attenuation in granite increases markedly as the strain amplitude is increased from $5 \times 10^{-7}$ to $5 \times 10^{-4}$ (Haupt et al., 1992). The transition to frequency-dependent attenuation occurs at strain amplitudes approaching $10^{-5}$ for dry granite and $10^{-6}$ for saturated granite. The frequency shift observed for the granite is most likely related to flow within the pores. The absence of any strain amplitude dependence in the saturated specimens of the tuff is probably because the time constant for diffusion is short for the pore geometry in the tuff and the experimental boundary conditions.

\subsection{CONCLUSIONS}

The effects of frequency and water saturation on Young's modulus and on attenuation for selected samples of the Paintbrush Tuff formation on and near Yucca Mountain have been studied. The experiments were conducted at room temperature and pressure using a variety of techniques to span the frequency range from $10^{-2}$ to $10^{6} \mathrm{~Hz}$. The data indicate that frequency has a limited effect on the modulus as well as on the attenuation over the entire frequency range. A small frequency dependence was observed for saturated samples. The effects of pressure and strain amplitude on modulus and attenuation were also very small at least for welded tuff. (In this context, small is used in comparison to what is normally observed in crystalline rocks with low aspect ratio cracks.) The results of these measurements are consistent with theoretical models that have been developed. Since 
the tuff is composed primarily of ellipsoidal and spherical pores, small pressure and strain amplitude dependencies were anticipated. The effect of saturation is to reduce Young's modelus by several percent in most instances. Water saturation also tended to increase the attenuation at each frequency.

The measurements of seismic wave velocity, Young's modulus, and attenuation reported are important, not only to constrain the microstructure of the tuff but also important in correlating laboratory scale properties with field measurements. At least two types of seismic surveys have been carried out at Yucca Mountain; surface seismic and vertical seismic profiling. The acoustic and mechanical data in this study can be used to constrain the seismic sections. We have shown that the modulus is independent of frequency at least for dry specimens. Since many of the rocks of interest are above the water table the velocity data collected, particularly on the dry specimens can be directly applied to the data.

The velocity and attenuation data for dry and saturated conditions at low frequencies (less than $100 \mathrm{~Hz}$ ) can be incorporated into seismic response models. The data is relevant to calculations of the seismic response due to earthquake loading at the potential repository. These models are extremely important in predicting the response of rock units to seismic (earthquake) forcing. 


\subsection{REFERENCES}

Bulau, J. R., B. R. Tittmann, M. Abdel-Gawad, and C. Salvado, 1984, The Role of Aqueous Fluids in the Internal Friction of Rock: J. Geophys. Res. 89(B6), 4207-4212. (NNA.930215.0042)

Coyner, Karl B., 1984, Effects of Stress, Pore Pressure, and Pore Fluids on Bulk Strain, Velocity, and Peremeability in Rocks: Ph.D. Thesis, Massachusetts Institute of Technology. (NNA.930330.0062)

Dunn, K. J., 1986, Acoustic Attenuation in Fluid-Saturated Porous Cylinders at Low Frequencies: J. Acoustic Soc. Am. 79(6), 1709-1721. (NNA.920218.0003)

Dunn, K. J., 1987, Sample Boundary Effect in Acoustic Attenuation of Fluid-Saturated Porous Cylinders: J. Acoustic Soc. Am. 81(5), 1259-1266. (NNA.920218.0004)

Gardner, G. H. F., 1962, Extensional Waves in Fluid-Saturated Porous Cylinders: J. Acoustic Soc.Am. 34(1), 36-40.(NNA.920218.0005)

Gordon, R. B., and L. A. Davis, 1968, Velocity and Attenuation of Seismic Waves in Imperfectly Elastic Rock: J. Geophys. Res. 73, 3917-3935.(NNA.920218.0007)

Haupt, R. W., R. J. Martin, X. Tang, W. Dupree, and R. H. Price, 1992"Modulus Dispersion and Attenuation in Tuff and Granite", Proc. 33rd U.S. Symposium on Rock Mechanics, Tillerson and Wawersik, W. (ed),899-908.(NNA.930824.0002) Lucet, N., P. N. Rasolofosaon, and B. Zinsner, 1991, Sonic Properties of Rocks Under Confining Pressure Using the Resonant Bar Technique: J. Acoustic Soc. Am. 89(3), 980-990.(NNA.920225.0038)

Mavko, G. M., 1979, Frictional Attenuation: An Inherent Amplitude Dependence: J.

Geophys. Res. 84, 4769-4775.(NNA.920218.0008)

Mavko, G. and A. Nur, 1979, Wave Attenuation in Partially Saturated Rocks: Geophysics 44, 161-178.(NNA.920218.0009)

Murphy, W. F., III, 1982, Effects of Partial Water Saturation on Attenuation in Massillon Sandstone and Vycor Porous Glass: J. Acoustic Soc. Am. 71(6), 1458-1468. (NNA.930224.0138)

Murphy, W. F., III, K.W. Winkler and R.L. Kleinberg, 1984, Frame Modulus Reduction in Sedimentary Rocks: The Effect of Adsorption on Grain Contacts: J. Geophys. Res. Lett., 9, 805-808. (NNA.920218.0010)

O'Connell, R. J. and B. Budiansky, 1977, Viscoelastic Properties of Fluid-Saturated Cracked Solids: J. Geophys. Res. 82, 5719-5735. (NNA.920218.0012)

Oritz, T. S., R. L. Williams, F. B. Nimick, B. C. Whittet, and D. L, South, 1985, A Three Dimensional Model of Reference Thermal/mechanical and Hydrologic Stratigraphy at Yucca Mountain, Southem Nevada: SAND84-1076, Sandia National Laboratories Albuquerque, NM. (NNA.890315.0013) 
Paffenholz, J. and H. Burkhardt, 1989, Absorption and Modulus Measurements in the Seismic Frequency and Strain Range on Partially Saturated Sedimentary Rocks: J. Geophys. Res. 94, 9493-9507. (NNA.920218.0013)

Prise, R. H., J. R. Connolly, and K. Keil, 1987, Petrologic and Mechanical Properties of Outcrop Samples of the Welded, Devitified Topopah Spring Member of the Paintbrush Tuff: Sandia Report, SAND86-1131 UC-70. (HQS.880517.1704)

Spencer, J. W., 1981, Stress Relaxations at Low Frequencies in Fluid-Saturated Rocks: Attenuation and Modulus Dispersion: J. Geophys. Res. 86, 1803-1812. (NNA.920218.0015)

Tang, X., 1992, A Waveform Inversion Technique for Measuring Elastic Wave Attenuation in Cylindrical Bars: Geophys. 57, 854-859. (NNA.921112.0081)

Tittmann, B. R., V. A. Clark, J.M. Richardson, and T.W. Spencer, 1980, Possible Mechanism for Seismic Wave Attenuation in Rocks Containing Small Amounts of Volatiles, J. Geophys. Res., 85, 5199-5208. (NNA.930215.0043)

Toksöz, M. N., D. H. Johnston, and A.Timur, 1979, Attenuation of Seismic Waves in Dry and Saturated Rocks: I. Laboratory Measurements: Geophys. 44, 681-690. (NNA.920218.0016)

Toksöz, M. N., and D. H. Johnston, 1981, Seismic Wave Attenuation: Geophys. reprint series, No.2. (NNA.930414.0034)

Toksöz, M. N., B. Mandal, and A. M. Dainty, 1990, Frequency Dependent Attenuation in the Crust, Geophys. Res. Lett., 17, 973-976. (NNA.931012.0003)

Walsh, J. B., 1969, Seismic Wave Attenuation in Rock Due to Friction: J. Geophys. Res. 71, 2591-2599. (NNA.930215.0044)

White, E. J., 1986, Biot-Gardner Theory of Extensional Waves in Porous Rocks: Geophysics, 51, 742-745. (NNA.920218.0017)

Winkler, D., A. Nur, and M. Gladwin, 1979, Friction and Seismic Attenuation in Rocks Nature 277, 528-531. (NNA.920218.0018) 


\title{
Appendix \\ Information from the Reference Information Base \\ Used in this Report
}

This report contains no information from the Reference Information Base.

\author{
Candidate Information \\ for the \\ Reference Information Base
}

This report contains no candidate information fro the Reference Information Base.

\author{
Candidate Information \\ for the \\ Geographic Nodal Information Study \\ and Evaluation System
}

This report contains no candidate information for the Geographic Nodal Information Study and Evaluation System. 


\section{YUCCA MOUNTAIN SITE CHARACTERIZATION PROJECT}

\section{DISTRIBUTION LIST}

1

D.A. Dreyfus (RW-1)

Director

OCRWM

US Department of Energy

1000 Independence Avenue SW

Washington, DC 20585

1 L.H. Barrett (RW-2)

Acting Deputy Director

OCRWM

US Department of Energy

1000 Independence Avenue SW

Washington, DC 20585

1

J.D. Saltzman (RW-4)

Omce of Strategjc Planning and

International Programs

OCRWM

US Department of Energy

1000 Independence Avenue SW

Washington, DC 20585

1

J.D. Saltzman (RW-5)

Once of External Relations

OCRWM

US Department of Energy

1000 Independence Avenue SW

Washington, DC 20585

1 Samuel Rousso (RW-10)

Onice of Program and Resource Mgt.

OCRWM

US Department of Energy

1000 Independence Avenue SW

Washington, DC 20585

1 J. C. Bresee (RW-10)

OCRWM

US Department of Energy

1000 Independence Avenue SW

Washington, DC 20585
1

R.M. Nelson (RW-20)

Omice of Geologic Disposal

OCRWM

US Department of Energy

1000 Independence Avenue, $\mathrm{SW}$

Washington, DC 20585

1 S. J. Brocoum (RW-22)

Analysis and Verification Division

OCRWM

US Department of Energy

1000 Independence Avenue SW

Washington, DC 2585

1

D. Shelor (RW-30)

Ofice of Systems and Compliance

OCRWM

US Department of Energy

1000 Independence Avenue, $\mathrm{SW}$

Washington, DC 20585

1 J. Roberts (RW-33)

Director, Regulatory Compliance

Division

OCRWM

US Department of Energy

1000 Independence Avenue, SW

Washington, DC 20585

1

G. J. Parker (RW-332)

Reg. Policy/Requirements Branch OCRWM

US Department of Energy

1000 Independence Avenue, SW

Washington, DC 20585

1 R. A. Milner (RW-40)

Ofiice of Storage and

Transporation

OCRWM

US Department of Energy

1000 Independence Avenue, SW

Washington, DC 20585

Distribution - 1 
S. Rousso (RW-s0)

Once of Contract Business

Management

OCRWM

US Department of Enerzy

1000 Independence Avenue, SW

Washington, DC 20585

1 T. Wood (RW-S2)

Diretor, M\&O Management Division

OCRWM

US Department of Energy

1000 Independence Avenue, SW

Washington, DC 20585

4 Victoria F. Reich, Lbrarian

Nuclear Waste Technical Review Boerd

1100 Wilson Blvd, Sulte 910

Arlington, VA 22209

5

R.M. Nelson Jr, Acting Project Manager

Yucen Mountain Site

Characterization Omice

US Department of Energy

P.O. Box 98608-MS 523

Las Vegas, NV 89193-8608

1

C. L. West, Director

Once of External Afiairs

DOE Nevada Field Omce

US Department of Energy

P.O. Box 98518

Las Vegas, NV 89193-8518

8 Technical Information Omicer

DOE Nevada Field Onice

US Department of Energy

P.O. Box 98518

Las Vegas, NV 89193-8518

1 P. K. Fitzsimmons, Technical Advisor

Omice of Assistant Manager for

Environmental Safety and

Health

DOE Nevada Field Onice

US Department of Energy

P.O. Box 98518

Las Vegas, NV 89193-8518
D. R. Elle, Director

Environmental Protection and Division

DOE Nevada Field Onice

US Department of Energy

P.0. Box 98518

Las Vegas, NV 89193-8518

1

Repository Licensing \& Quality

Assurance

Project Directorate

Division of Waste Management

US NRC

Washington, DC 20555

1

Senior Project Manager for Yucca

Mountain

Repository Project Branch

Division of Waste Management

US NRC

Washington, DC 20555

1

NRC Document Control Desk

Division of Waste Management

US NRC

Washington, DC 20555

$1 \quad$ Philip S. Justus

NRC Site Representive

301 E Stewart Avenue, Room 203

Las Vegas, NV 89101

1 E. P. Binnall

Field Systems Group Leader

Building 50B/4235

Lawrence Berkeley Laboratory

Berkeley, CA 94720

1 Center for Nuclear Waste

Regulatory Analyses

6220 Culebra Road

Drawer 28510

San Antonio, TX 78284

3

W. L. Clarke

Technical Project Omicer - YMP

Attn: YMP/LRC

Lawrence Livermore National

Laboratory

P.O. Box 5514

Uvermore, CA 94551

Distribution - 2 
Deputy Project Leader

Lowrence Livermore National

Laboratory

101 Convention Center Drive

Suite 820, MS 527

Las Vegas, NV 89109

4

J. A. Canepa

Technical Project Omcer - YMP

N-S, Mail Stop J521

Los Alamos National Laboratory

P.O. Box 1663

Los Alamos, NM 87545

1 H. N. Kalia

Exploratory Shaft Test Manager

Los Alamos National Laboratory

Mail Stop 527

101 Convention Center Dr., \#820

Las Vegas, NV 89101

1

N. Z. Elkins

Deputy Technical Project Omicer

Los Alamos National Laboratory Mail Stop 527

101 Convention Center Dr., \#820

Las Vegas, NV 89101

5 L. E. Shephard

Technical Project Omicer - YMP

Sandia National Laboratories

Organization 6302, M/S 1333

P.O. Box 5800

Albuquerque, NM 87185

1

J. F. Devine

Asst Director of Engineering Geology

US Geological Survey

106 National Center

12201 Sunrise Valley Drive

Reston, VA 22092

1
1

\author{
V. R. Schnelder \\ Asst. Chief Hydrologist-MS $\mathbf{4 1 4}$ \\ Omce of Program Coordination \\ and Technical Support \\ US Geological Survey \\ 12201 Sunrise Valley Drive \\ Reston, VA 22092
}

1

J. S. Stuckless

Geologic Division Coordinator

MS 913

Yucca Mountain Project

US Geological Survey

P.O. Box 25046

Denver, CO 80225

1

D. H. Appel, Chief

Hydrologic Investigations Program

MS 421

US Geological Survey

P.O. Box 25046

Denver, CO 80225

1 E. J. Helley

Branch of Western Regional Geology

MS 427

US Geological Survey

345 Middlefield Road

Menlo Park, CA 94025

1 R. W. Craig, Chief

Nevada Operations Omce

US Geological Survey

101 Convention Center Drive

Suite 860, MS 509

Las Vegas, NV 89109

1

D. Zesiger

US Geological Survey

101 Conventional Center Drive

Suite 860, MS 509

Las Vegas, NV 89109

1

G. L. Ducret, Associate Chief

Yucca Mountain Project Division

US Geological Survey

P.O. Box 25046

421 Federal Center

Denver, CO 80225

Distribution - 3 
US Geological Survey

MS 721

P.O. Box 327

Mercury, NV 89023

1 D. A. Beck

Water Resources Division, USGS

6770 S Paradise Road

Las Vegas, NV 89119

1

P. A. Glancy

US Geological Survey

Federal Building, Room 224

Carson City, NV 89701

1 Sherman S.C. Wu

US Geological Survey

2255 N. Geminl Drive

Flagstaf, AZ 86001

1 J. H. Sass - USGS

Branch of Tectonophysics

2255 N Gemini Drive

Flagstan, AZ 86001

1 DeWayne Campbell

Technical Project Omcer - YMP

US Bureau of Reclamation

Code D-3790

P.O. Box 25007

Denver, CO 80225

1 J. M. LaMonaca

Records Specialist

US Geological Survey

421 Federal Center

P.O. Box 25046

Denver, CO 80225

1

W. R. Keefer - USGS

913 Federal Center

P.O. Box 25046

Denver, CO 80225

1 M. D. Voegele

Technical Project Oficer - YMP

SAIC

101 Convention Center Drive

Sulte $\mathbf{4 0 7}$

Las Vegas, NV 89109
L. D. Foust

Nevada Site Manager

TRW Environmental Safety

Systems

101 Convention Center Drive

Sulte 540, MS 423

Las Vegas, NV 89109

1

C. E. Ezra

YMP Support Omce Manager

EG\&G Energy Measurements Inc MS V-02

P.O. Box 1912

Las Vegas, NV 89125

1 Jan Docka

Roy F. Weston Inc

955 L'Enfant Plaza SW

Washington, DC 20024

1 Technical Information Center

Roy F. Weston Inc

955 L'Enfant Plaza SW

Washington, DC 20024

1

D. Hedges, Vice President, QA

Roy F. Weston Inc

4425 Spring Mountain Road

Suite 300

Las Vegas, NV 89102

1

D. L. Fraser, General Manager

Reynolds Electrical \&

Engineering Co, Inc

MS 555

P.0. Box 98521

Las Vegas, NV 89193-8521

1

B. W. Colston, President and

General Manager

Las Vegas Branch

Raytheon Services Nevada

MS 416

P.O. Box 95487

Las Vegas, NV 89193-5487

1

R. L. Bullock

Technical Project Omicer - YMP

Raytheon Services Nevada

Suite P-250, MS 403

101 Convention Center Drive

Las Vegas, NV 89109

Distribution - 4 
PASS Program

Pacific Northwest Laboratories

P.O. Box 999

Richland, WA 99352

1

A. T. Tamura

Science and Technology Division

OSTI

US Department of Energy

P.O. Box 62

Oak Ridge, TN 37831

1 Carlos G. Bell Jr

Professor of Civil Engineering

Civil and Mechanical Engineering Dept.

University of Nevada, Las Vegas

4505 S Maryland Parkway

Las Vegas, NV 89154

P. J. Weeden, Acting Director

Nuclear Radiation Assessment Div.

US EPA

Environmental Monitoring

Systems Lab

P.O. Box 93478

Las Vegas, NV 89193-3478

$1 \quad$ ONWI Lbrary

Battelle Columbus Laboratory

Once of Nuclear Waste Isolation

505 King Avenue

Columbus, OH 43201

1 T. Hay, Executive Assistant

Omice of the Governor

State of Nevada

Capitol Complex

Carson City, NV 89710

3

R. R. Loux

Executive Director

Agency for Nuclear Projects

State of Nevada

Evergreen Center, Suite 252

1802 N. Carson Street

Carson City, NV 89710
1

C.H. Johnson
Technical Program Manager

Agency for Nuclear Projects

State of Nevada

Evergreen Center, Sulte 252

1802 N. Carson Street

Carson Clty, NV 89710

1 John Fordham

Water Resources Center

Desert Research Institute

P.O. Box 60220

Reno, NV 89506

1 David Rhode

Desert Research Institute

P.O. Box 60220

Reno, NV 89506

1

Eric Anderson

Mountain West Research-

Southwest Inc

2901 N Central Avenue \#1000

Phoenix, AZ 85012-2730

1 The Honorable Cyril Schank

Chairman

Churchill County Board of

Commissioners

$190 \mathrm{~W}$ First Street

Fallon, NV 89406

1 Dennis Bechtel, Coordinator

Nuclear Waste Division

Clark County Department of

Comprehensive Planning

301 E Clark Avenue, Suite 570

Las Vegas, NV 89101

1 Juanita D. Hoffiman

Nuclear Waste Repository

Oversight Program

Esmeralda County

P.O. Box 490

Goldfield, NV 89013

1 Eureka County Board of Commissioners

Yucca Mountain Information

Once

P.O. Box 714

Eureka, NV 89316

Distribution - 5 
1 Brad Mettam

Inyo County Yucca Mountain

Repository Assessment Oilce

Drawer L

Independence, CA 93526

1 Lander County Board of

Commissioners

315 South Humbolt

Battle Mountain, NV 89820

1 Veruon E. Poe

Oilce of Nuclear Projects

Mineral County

P.O. Box 1026

Hawthorne, NV 89415

1 Les W. Bradshaw

Program Manager

Nye County Nuclear Waste

Repository Program

P.0. Box 153

Tonopah, NV 89049

1 Florindo Mariani

White Pine County Nuclear

Waste Project Once

457 Finth Street

Ely, NV 89301

1 Judy Foremaster

City of Callente Nuclear Waste

Prolect Onice

P.O. Box 158

Callente, NV 89008

1 Phillip A. Niedxlelsk-Eichner

Nye County Nuclear Waste

Repository Project Onice

P.O. Box 221274

Chantilly, VA 22022-1274

1 Jason Pitts

Uncoln County Nuclear Waste

Project Onice

Uncoln County Courthouse

Pioche, NV 89043
1 Dconomic Development Dept.

City of Las Veqas

400 E. Stewart Avenue

Las Vegns, NV 89101

1 Commmunity Planning and

Development

City of North Las Vergs

P.O. Box $40: 6$

North Las Vegas, NV 89030

1

Community Development and

Planning

City of Boulder City

P.O. Box 61350

Boulder City, NV 89006

1 Commission of the European

Communities

200 Rue de la Lod

B-1049 Brussells

BELGIUM

2

M. J. Dorsey, Lbrarian

YMP Research and Study Center

Reynolds Electrical \&

Engineering Co Inc

MS 407

P.0. Box 98521

Las Vegas, NV 89193-8521

1 Amy Anderson

Argonne National Laboratory

Building 362

9700 S Cass Avenue

Argonne, IL 60439

1 Steve Bradhurst

P.O. Box 1510

Reno, NV 89505

1 Michael Lo Baughman

35 Clark Road

Fiskdale, MA 01518

1 Glenn Van Roekel

Director of Community

Development

City of Callente

P.O. Box 158

Callente, NV 89008 
1

Ray Williams, Jr

P.O. Box 10

Austin, NV 89310

1 Nye County District Attorney

P.0. Box 593

Tonopah, NV 89049

1 Wiliam OTutt

Nye County Manager

Tonopah, NV 89049

1 Charles Thistlethwaite, AICP

Associate Planner

Inyo County Planning Department

Drawer L

Independence, CA 93526

1 R. F. Pritchett

Technical Project Omcer - YMP

Reynolds Electrical \&

Engineering Company Inc

MS 408

P.O. Box 98521

Las Vegas, NV 89193-8521

1

Dr. Moses Karakouzian

1751 E Reno \#125

Las Vegas, NV 89119

10

\section{RJ. Martin III}

MS

$1 \quad 132$

21330

21330

$20 \quad 1330$

$1 \quad 1324$

$1 \quad 0827$

$1 \quad 1375$

$20 \quad 1325$

10751

$5 \quad 0899$

10619

100100

19018
LS. Costin, 6313

G.M. Gerstmer-Miller, 6352 100/1232713/SAND92-0347/QA

G.M. Gerstner-Miller, 6352

DRMS Files

WMT Llbrary, 6352

P.B. Davies, 6115

P.J. Hommert, 1502

D.A. Dahlgren, 4400

R.H. Price, 6313

W.R. Wawerslk, 6117

Technical Lubrary, 13414

Technical Publications, 13416

Document Processing for

DOE/OSTI, 7613-2

Central Technical Flles, 8523-2

New England Research Inc

76 Olcott Drive

White River Junction, VT 05001 
